\title{
Copper(I) Oligomers and Polymers with Dicyanobenzene and
}

\section{Cyanopyridine Ligands.}

\author{
Mark K. Broderick, Congqi Yang, and Robert D. Pike* \\ Department of Chemistry, College of William and Mary, Williamsburg, VA 23187. \\ Aaron Nicholas, Daniel May and Howard H. Patterson \\ Department of Chemistry, University of Maine, Orono, ME 04469.
}

\begin{abstract}
The reaction of $\left[\mathrm{Cu}(\mathrm{MeCN})_{4}\right] \mathrm{BF}_{4}$ with $o-, m-$, or $p$-dicyanobenzene (DCB) or $o-, m-$, or p-cyanopyridine (CPy) in the presence of two equivalents of $\mathrm{PPh}_{3}$ produces $\mathrm{DCB}$ - or CPybridged copper(I) complexes. Cyclic dimers are formed for the ortho ligands, and zigzag polymers are formed using the para ligands. $m$-DCB produces a polymer, however $m$-CPy results in a cyclic trimer. Multiple lattice-bound solvates are formed upon crystallization of the $o$-DCB dimer from various solvents. A total of 11 X-ray crystal structures are reported for $\left[\mathrm{Cu}_{n}\left(\mathrm{PPh}_{3}\right)_{2 n}(\text { bridge })_{n}\right]\left(\mathrm{BF}_{4}\right)_{n} \bullet($ solvent $)$ : bridge $=o-\mathrm{DCB}, n=2$, solvent (per dimer) $=$ none, $1 / 2$ $\mathrm{CH}_{2} \mathrm{Cl}_{2}, \mathrm{CH}_{2} \mathrm{Cl}_{2}, 2 \mathrm{CHCl}_{3} / \mathrm{H}_{2} \mathrm{O}$, or $2 \mathrm{THF}$; bridge $=m$-DCB, $n=\infty$, solvent = none; bridge $=p$ DCB, $n=\infty$, solvent $=\mathrm{CH}_{2} \mathrm{Cl}_{2}$ (two polymorphs), bridge $=o$-CPy, $n=2$, solvent $($ per dimer $)=2$ toluene; bridge $=m$-CPy, $n=3$, solvent $=$ none; bridge $=p$-CPy, $n=\infty$, solvent $=1 / 2$ acetone. All complexes are photoluminescent with excitation in the range $340-400 \mathrm{~nm}$. The meta complexes emit in the blue region, while the other complexes emit in the green. Dimer complexes of $o$-DCB exhibit structural flexibility in the central macrocyclic ring. Complexes of $m$-DCB and $p$-CPy show orientational disorder in the ligand. Polymeric complexes show helicity. Smaller Stokes
\end{abstract}


shifts are noted for DCB than for CPy complexes, suggesting less excited state distortion for cyanoaromatic ligand complexes of $\mathrm{Cu}(\mathrm{I})$.

Keywords: Copper complexes; Crystal structures; Dicyanobenzene; Cyanopyridine; Dimer; Trimer; Metal-organic polymer; Luminescence; Solvento complexes

\section{Introduction}

The study of copper(I) networks has been particularly intensive in recent recent years as a result of the structural flexibility and diversity of this $\mathrm{d}^{10}$ center, as well as its diverse photophysical behavior [1]. The electronic transitions undergone by $\mathrm{Cu}(\mathrm{I})$ can include $\mathrm{d} \rightarrow \mathrm{p}$ metal-centered (MC), metal-to-ligand $\pi^{*}$ charge transfer (MLCT), halide-to-metal charge transfer (XMCT), and cluster-centered (CC) transitions. Lifetimes for the resulting excited states are typically in the $\mu$ s range, and thus are indicative of phosphorescence. The quantum yield values for some of these $\mathrm{Cu}(\mathrm{I})$ complexes have reached 0.5 or better; therefore, $\mathrm{Cu}(\mathrm{I})$ species have been investigated as potential organic light-emitting diode materials [2].

Bridging of $\mathrm{Cu}(\mathrm{I})$ centers by halide and pseudo halide ligands with or without additional bridging organic ligands produces networks with a wide and often unpredictable variety of structural motifs [3]. In contrast, the use of non-coordinating anions allows for greater control over networking behavior through manipulation of metal:organic ligand stoichiometry. Thus, when two bidentate bridging ligands per copper atom are used, 3-D diamondoid networks $\left[\mathrm{Cu}(\text { bridge })_{2}\right]^{+}$are typically produced [4]. The addition of monodentate "capping" ligands, may be used to reduce network dimensionality. For example, the use of two equivalents of $\mathrm{PPh}_{3}$ per $\mathrm{Cu}$ (I) produces the $\mathrm{Cu}\left(\mathrm{PPh}_{3}\right)_{2}{ }^{+}$secondary building unit (SBU), which has been shown to produce metal-organic polymers and oligomers with bridge $=$ pyrazine, 4,4'-dipyridine, and 3,4'-dipyridine 
[5],[6]. These compounds have been noteworthy for their formation of multiple crystalline forms containing various levels of solvation, and for emission that is highly dependent on solvation.

Nitrile $\mathrm{R}-\mathrm{C} \equiv \mathrm{N}-\mathrm{Cu}(\mathrm{I})$ bonding is well-recognized, in large measure due to the great importance of the acetonitrile ligand in copper(I) chemistry. Bridging polycyanoorganic ligands have been used to produce dimeric [7], polymeric [8], and network [9] complexes of copper(I). Amongst these categories, polymers and oligomers are less common. This is because most such compounds are ternary in nature, requiring the use of SBUs with capping ligands to restrict network growth. Here, we report the formation of dimers and polymers of the $\mathrm{SBU} \mathrm{Cu}\left(\mathrm{PPh}_{3}\right)_{2}^{+}$ using the isomers of dicyanobenzene (DCB) and cyanopyridine (CPy) as bridging ligands.

\section{Experimental}

\subsection{General methods}

All syntheses were carried out under nitrogen or argon atmosphere. Microanalyses for C, $\mathrm{H}$, and $\mathrm{N}$ were carried out by Atlantic Microlab, Inc., Norcross, GA. All ligands were purchased from Aldrich or Acros. $o$-Dicyanobenzene (oDCB) and $m$-dicyanobenzene (mDCB) were recrystallized from 95\% ethanol, and $m$-cyanopyridine (mCPy) was recrystallized from xylenes/hexanes. All other ligands were used as received. $\left[\mathrm{Cu}(\mathrm{NCMe})_{4}\right] \mathrm{BF}_{4}$ was prepared from $\mathrm{Cu}_{2} \mathrm{O}$ and $\mathrm{HBF}_{4}$ in acetonitrile as described in the literature [10]. Toluene was dried over $\mathrm{CaH}_{2}$. Proton NMR spectra were collected in $5 \mathrm{~mm}$ o.d. NMR tubes on a Varian Mercury 400VX NMR spectrometer operating in the pulse Fourier transform mode. Chemical shifts were measured with respect to internal solvent. All coupling constants are reported in $\mathrm{Hz}$ and $J_{\mathrm{HH}}$. Thermogravimetric analyses (TGA) were conducted using a TA Instruments Q500 in the dynamic (variable temp.) mode with a maximum heating rate of $50{ }^{\circ} \mathrm{C} / \mathrm{min}$. to $800{ }^{\circ} \mathrm{C}$ under $60 \mathrm{~mL} / \mathrm{min} . \mathrm{N}_{2}$ flow. Steadystate photoluminescence spectra were recorded with a Model QuantaMaster-1046 photoluminescence spectrophotometer from Photon Technology International. The instrument 
was equipped with two excitation monochromators and a single emission monochromator with a $75 \mathrm{~W}$ xenon lamp.

\subsection{Synthesis of Complexes}

$\left[C u_{2}\left(P P h_{3}\right)_{4}(\mathrm{ODCB})_{2}\right]\left(B F_{4}\right)_{2}(\mathbf{1})$

$\left[\mathrm{Cu}(\mathrm{NCMe})_{4}\right] \mathrm{BF}_{4}(315 \mathrm{mg}, 1.00 \mathrm{mmol})$ and $\mathrm{PPh}_{3}(525 \mathrm{mg}, 2.00 \mathrm{mmol})$ were suspended in $20 \mathrm{~mL}$ dry toluene. To this mixture solid oDCB $(128 \mathrm{mg}, 1.00 \mathrm{mmol})$ was added, producing a white suspension. The mixture was refluxed overnight, forming a pale yellow suspension. The solid was collected via filtration, washed with ethyl ether, and dried under vacuum $(755 \mathrm{mg}$, $0.470 \mathrm{mmol}, 94 \%$ yield). ${ }^{1} \mathrm{H}$ NMR $\left(\mathrm{CDCl}_{3}\right) \delta 7.88(\mathrm{~m}, 4 \mathrm{H}, \mathrm{oDCB}), 7.84(\mathrm{~m}, 4 \mathrm{H}, \mathrm{oDCB}), 7.38(\mathrm{t}$, $\left.\mathrm{J}=6.8,12 \mathrm{H}, \mathrm{PPh}_{3}\right), 7.26\left(\mathrm{~m}, 48 \mathrm{H}, \mathrm{PPh}_{3}\right)$. Anal. Calcd for $\mathrm{C}_{88} \mathrm{H}_{68} \mathrm{~N}_{4} \mathrm{~B}_{2} \mathrm{Cu}_{2} \mathrm{~F}_{8} \mathrm{P}_{4}: \mathrm{C}, 65.81 ; \mathrm{H}$, 4.27; N, 3.49. Found: C, 64.78; H, 4.36; N, 3.71. TGA Calcd for $\mathrm{Cu}_{2}\left(\mathrm{PPh}_{3}\right)_{4}\left(\mathrm{BF}_{4}\right)_{2}:$ 84.1. Found: $84.2\left(175-225^{\circ} \mathrm{C}\right)$. Calcd for $\mathrm{CuBF}_{4}$ : 14.8 . Found: $18.7\left(225-275^{\circ} \mathrm{C}\right)$. Calcd for $\mathrm{CuF}$ : 9.5. Found: $9.8\left(350-560^{\circ} \mathrm{C}\right)$.

$\left\{\left[\mathrm{Cu}\left(\mathrm{PPh}_{3}\right)_{2}(\mathrm{mDCB})\right]\left(\mathrm{BF}_{4}\right)\right\}_{\infty}(2)$

The procedure for 1 was followed using $\mathrm{mDCB}$. A white solid was isolated $(93 \%) .{ }^{1} \mathrm{H}$ $\operatorname{NMR}\left(\mathrm{CDCl}_{3} / \mathrm{DMSO}^{-\mathrm{D}_{6}}\right) \delta 8.38(\mathrm{~s}, 1 \mathrm{H}, \mathrm{mDCB}), 8.14(\mathrm{~d}, \mathrm{~J}=8.0,2 \mathrm{H}, \mathrm{mDCB}), 7.79(\mathrm{t}, \mathrm{J}=7.8,1$ $\mathrm{H}, \mathrm{mDCB}), 7.47$ (t, J = 7.4, $6 \mathrm{H}, \mathrm{PPh}_{3}$ ), 7.36 (t, J = 7.6, $\left.12 \mathrm{H}, \mathrm{PPh}_{3}\right), 7.29$ (br s, $12 \mathrm{H}, \mathrm{PPh}_{3}$ ). Anal. Calcd for $\mathrm{C}_{44} \mathrm{H}_{34} \mathrm{~N}_{2} \mathrm{BCuF}_{4} \mathrm{P}_{2}$ : C, 65.81; H, 4.27; N, 3.49. Found: C, 64.16; H, 4.26; N, 3.47. TGA Calcd for $\mathrm{Cu}_{2}\left(\mathrm{PPh}_{3}\right)_{4}\left(\mathrm{BF}_{4}\right)_{2}$ : 84.1. Found: $83.7\left(190-235^{\circ} \mathrm{C}\right)$. Calcd for $\mathrm{CuBF}_{4}$ : 14.8. Found: 12.6 (235-280 $\left.{ }^{\circ} \mathrm{C}\right)$. Calcd for CuF: 9.5. Found: $9.5\left(280-465^{\circ} \mathrm{C}\right)$.

$\left\{\left[C u\left(P P h_{3}\right)_{2}(p D C B)\right]\left(B F_{4}\right)\right\}_{\infty}(3)$

The procedure for $\mathbf{1}$ was followed using pDCB. A yellow solid was isolated $(92 \%) .{ }^{1} \mathrm{H}$ NMR $\left(\mathrm{CDCl}_{3} / \mathrm{DMSO}_{6}\right) \delta 8.04(\mathrm{~s}, 4 \mathrm{H}, \mathrm{pDCB}), 7.47\left(\mathrm{t}, \mathrm{J}=7.4,6 \mathrm{H}, \mathrm{PPh}_{3}\right), 7.36(\mathrm{t}, \mathrm{J}=7.4,12$ $\mathrm{H}, \mathrm{PPh}_{3}$ ), 7.29 (br s, $12 \mathrm{H}, \mathrm{PPh}_{3}$ ). Anal. Calcd for $\mathrm{C}_{44} \mathrm{H}_{34} \mathrm{~N}_{2} \mathrm{BCuF}_{4} \mathrm{P}_{2}$ : C, 65.81; H, 4.27; N, 3.49. Found: C, 65.66; H, 4.41; N, 3.46. TGA Calcd for $\mathrm{Cu}_{2}\left(\mathrm{PPh}_{3}\right)_{4}\left(\mathrm{BF}_{4}\right)_{2}$ : 84.1. Found: 80.8 (180-240 
$\left.{ }^{\circ} \mathrm{C}\right)$. Calcd for $\mathrm{CuBF}_{4}: 14.8$. Found: $15.8\left(240-275^{\circ} \mathrm{C}\right)$. Calcd for CuF: 9.5. Found: $11.6(295-455$

$\left.{ }^{\circ} \mathrm{C}\right)$.

$\left[\mathrm{Cu}_{2}\left(\mathrm{PPh}_{3}\right)_{4}(\mathrm{oCPy})_{2}\right]\left(\mathrm{BF}_{4}\right)_{2}(4)$

The procedure for $\mathbf{1}$ was followed using oCPy. A golden-yellow solid was isolated (77\%). ${ }^{1} \mathrm{H}$ NMR $\left(\mathrm{CDCl}_{3}\right) \delta 8.43(\mathrm{~d}, \mathrm{~J}=7.8,2 \mathrm{H}, \mathrm{oCPy}), 8.01(\mathrm{t}, \mathrm{J}=7.8,1 \mathrm{H}, \mathrm{oCPy}), 7.44(\mathrm{~s}, 1 \mathrm{H}$, oCPy), 7.38 (t, J = 7.4, $6 \mathrm{H}, \mathrm{PPh}_{3}$ ), 7.24 (t, $\mathrm{J}=8.0,12 \mathrm{H}, \mathrm{PPh}_{3}$ ), 7.16 (br s, $12 \mathrm{H}, \mathrm{PPh}_{3}$ ). Anal. Calcd for $\mathrm{C}_{84} \mathrm{H}_{68} \mathrm{~N}_{4} \mathrm{~B}_{2} \mathrm{Cu}_{2} \mathrm{~F}_{8} \mathrm{P}_{4}: \mathrm{C}, 64.76 ; \mathrm{H}, 4.40 ; \mathrm{N}, 3.60$. Found: C, 64.52; H, 4.73; N, 3.59. TGA Calcd for $\mathrm{CuBF}_{4}$ : 19.3. Found: 19.4 (80-290 $\left.{ }^{\circ} \mathrm{C}\right)$. Calcd for CuF: 10.6. Found: 10.1 (290$\left.500{ }^{\circ} \mathrm{C}\right)$.

$\left[C u_{3}\left(P P h_{3}\right)_{6}(m C P y)_{3}\right]\left(B F_{4}\right)_{3}(5)$

The procedure for 1 was followed using mCPy. A white solid was isolated $(83 \%) .{ }^{1} \mathrm{H}$ $\operatorname{NMR}\left(\mathrm{CDCl}_{3}\right) \delta 8.69(\mathrm{~d}, \mathrm{~J}=5.1,3 \mathrm{H}, \mathrm{mCPy}), 8.63(\mathrm{~s}, 3 \mathrm{H}, \mathrm{mCPy}), 7.92(\mathrm{dt}, \mathrm{J}=8.2,1.8,3 \mathrm{H}$, mCPy), $7.56(\mathrm{dd}, \mathrm{J}=8.3,5.5,3 \mathrm{H}, \mathrm{mCPy}), 7.38\left(\mathrm{t}, \mathrm{J}=7.4,18 \mathrm{H}, \mathrm{PPh}_{3}\right), 7.18(\mathrm{t}, \mathrm{J}=7.7,36 \mathrm{H}$, $\mathrm{PPh}_{3}$ ), 7.04 (br s, $36 \mathrm{H}, \mathrm{PPh}_{3}$ ). Anal. Calcd for $\mathrm{C}_{126} \mathrm{H}_{102} \mathrm{~N}_{6} \mathrm{~B}_{3} \mathrm{Cu}_{3} \mathrm{~F}_{12} \mathrm{P}_{6}$ : C, 64.76; H, 4.40; N, 3.60. Found: C, 63.70; H, 4.44; N, 3.24. TGA Calcd for $\mathrm{Cu}_{2}\left(\mathrm{PPh}_{3}\right)_{4}\left(\mathrm{BF}_{4}\right)_{2}$ : 86.6. Found: 86.4 (135-235 $\left.{ }^{\circ} \mathrm{C}\right)$. Calcd for $\mathrm{CuBF}_{4}:$ 19.3. Found: $13.7\left(235-270{ }^{\circ} \mathrm{C}\right)$. Calcd for $\mathrm{CuF}$ : 9.9. Found: 10.7 (350-455 $\left.{ }^{\circ} \mathrm{C}\right)$.

$\left\{\left[C u\left(P P h_{3}\right)_{2}(p C P y)\right]\left(B F_{4}\right)\right\}_{\infty}(6)$

The procedure for $\mathbf{1}$ was followed using pCPy. A bright yellow solid was isolated (96\%). ${ }^{1} \mathrm{H} \mathrm{NMR}\left(\mathrm{CDCl}_{3} / \mathrm{DMSO}_{-} \mathrm{d}_{6}\right) \delta 8.87$ (br s, $\left.2 \mathrm{H}, \mathrm{pCPy}\right), 7.79$ (br s, $\left.2 \mathrm{H}, \mathrm{pCPy}\right), 7.46$ (t, J = 7.4, $6 \mathrm{H}$, $\mathrm{PPh}_{3}$ ), 7.35 (t, J = 7.7, $12 \mathrm{H}, \mathrm{PPh}_{3}$ ), 7.28 (br s, $12 \mathrm{H}, \mathrm{PPh}_{3}$ ). Anal. Calcd for $\mathrm{C}_{42} \mathrm{H}_{34} \mathrm{~N}_{2} \mathrm{BCuF}_{4} \mathrm{P}_{2}: \mathrm{C}$, 64.76; H, 4.40; N, 3.60. Found: C, 64.48; H, 4.47; N, 3.59. TGA Calcd for $\mathrm{Cu}_{2}\left(\mathrm{PPh}_{3}\right)_{4}\left(\mathrm{BF}_{4}\right)_{2}$ : 86.6. Found: $85.9\left(165-225{ }^{\circ} \mathrm{C}\right)$. Calcd for $\mathrm{CuBF}_{4}$ : 19.3. Found: $12.6\left(225-275{ }^{\circ} \mathrm{C}\right)$. Calcd for CuF: 9.9. Found: $9.6\left(335-455^{\circ} \mathrm{C}\right)$.

\subsection{Crystallizations}


All compounds except 3 and $\mathbf{6}$ were separately crystallized from $\mathrm{CHCl}_{3}$ and $\mathrm{CH}_{2} \mathrm{Cl}_{2}$ solutions with ether diffusion. Compound $\mathbf{3}$ was insufficiently soluble in $\mathrm{CHCl}_{3}$ and was crystallized from $\mathrm{CH}_{2} \mathrm{Cl}_{2}$ solution only; compound $\mathbf{6}$ was not soluble in either chlorinated solvent, and was therefore crystallized from acetone solution. Compound $\mathbf{1}$ was additionally crystallized from THF and acetone solutions. In all cases, the compound was dissolved in the appropriate solvent at $30 \mathrm{mM}$ (monomer basis) and the solution was layered in $5 \mathrm{~mm}$ tubes or 1 or 2 dram vials with ethyl ether and allowed to stand at ambient temperature. In all cases crystals resulted within a few days. Structures 1a, 1b, 1c, 3a, 3b, 4a, and $\mathbf{5}$ were solved from crystals grown in $\mathrm{CH}_{2} \mathrm{Cl}_{2}$ /ether. The structures of $\mathbf{1 d}$ and $\mathbf{2}$ were solved from crystals grown in $\mathrm{CHCl}_{3} /$ ether, and those of 1e and 6a were solved from crystals grown in THF/ether and acetone/ether, respectively.

\subsection{X-ray data collection, structure solutions and refinements}

All measurements were made using graphite-monochromated $\mathrm{Cu} \mathrm{K} \alpha$ radiation on a Bruker-AXS three-circle diffractometer, equipped with a SMART Apex II CCD detector. Initial space group determination was based on a matrix consisting of 120 frames. The data were corrected for Lorentz and polarization [11] effects and absorption using SADABS [12]. The structures were solved by use of intrinsic phasing or direct methods. Least squares refinement on $\mathrm{F}^{2}$ was used for all reflections. Structure solution was performed using the SHELXTL [13] package of software. Least-squares refinement was carried out for all structures on $F^{2}$ using ShelXle [14]. The non-hydrogen atoms were refined anisotropically. Crystallographic parameters for all complexes are provided in Table 2. Selected bond lengths and angles are provided in Table 3.

\section{Results and discussion}

\subsection{Synthesis}


Reaction of one equivalent of the solvento- $\mathrm{Cu}(\mathrm{I})$ compound $\left[\mathrm{Cu}(\mathrm{NCMe})_{4}\right] \mathrm{BF}_{4}$ with two equivalents of $\mathrm{PPh}_{3}$ and a single equivalent of $o-, m$-, or $p$-dicyanobenzene (oDCB, mDCB, $\mathrm{pDCB}$ ) or $o^{-}, m$ - or $p$-cyanopyridine (oCPy, $\mathrm{mCPy}, \mathrm{pCPy}$ ) in refluxing toluene yielded product compounds showing 1:2:1 stoichiometry $\mathrm{CuBF}_{4}: \mathrm{PPh}_{3}: \mathrm{DCB} / \mathrm{CPy}$. In order to replace all of the acetonitrile ligands, the toluene suspensions were refluxed for 18-20 hours prior to work-up. In each case, pure products were collected directly from the suspension after washing with ethyl ether. The carbon analyses for compounds 1, 2, and 5 were found to be $1.6-2.7 \%$ lower than expected, probably due to traces of included solvent. The six product compounds were formed in in good to nearly quantitative yield. The lowest yield was noted for the oCPy product (77\%), in which case only the toluene filtrate retained significant yellow color. The polymeric products of $\mathrm{mDCB}, \mathrm{pDCB}$, and $\mathrm{pCPy}$ described below were also formed when reactions were carried out in refluxing $\mathrm{CH}_{2} \mathrm{Cl}_{2}$ or $\mathrm{CHCl}_{3}$. However, in the cases of oDCB, oCPy, and $\mathrm{mCPy}$, reflux in chlorinated solvents led to the formation of the known bis(acetonitrile) complex, $\left[\mathrm{Cu}\left(\mathrm{PPh}_{3}\right)_{2}(\mathrm{NCMe})_{2}\right] \mathrm{BF}_{4}[15]$ rather than the oligomeric products decribed below. Therefore, the higher-boiling toluene was chosen as the preferred reaction solvent. In one case (oCPy complex, 4, see below) a toluene solvate was formed. The toluene could be removed from $\mathbf{4}$ via vacuum drying. However, crystallization of the undried product from $\mathrm{CH}_{2} \mathrm{Cl}_{2}$ /ether yielded a toluene solvate structure.

Although the $\mathrm{CuBF}_{4}: \mathrm{PPh}_{3}: \mathrm{DCB} / \mathrm{CPy}$ stoichiometry of all six complexes was determined to be 1:2:1 by elemental analysis, the degree of oligomerization as identified via X-ray crystallography (see below) varied depending upon the ligand used. Thus, the oDCB complex (1) proved to be a cyclic dimer: $\left[\mathrm{Cu}_{2}\left(\mathrm{PPh}_{3}\right)_{4}(\mathrm{oDCB})_{2}\right]\left(\mathrm{BF}_{4}\right)_{2}$, while the $\mathrm{mDCB}$ and pDCB products $(2$ and 3) were polymers: $\left\{\left[\mathrm{Cu}\left(\mathrm{PPh}_{3}\right)_{2}(\mathrm{mDCB})\right]\left(\mathrm{BF}_{4}\right)\right\}_{\infty}$ and $\left\{\left[\mathrm{Cu}\left(\mathrm{PPh}_{3}\right)_{2}(\mathrm{pDCB})\right]\left(\mathrm{BF}_{4}\right)\right\}_{\infty}$. Similar to their DCB analogs, oCPy yielded a cyclic dimer, $\left[\mathrm{Cu}_{2}\left(\mathrm{PPh}_{3}\right)_{4}(\mathrm{oCPy})_{2}\right]\left(\mathrm{BF}_{4}\right)_{2}$ (4) and pCPy produced a polymer $\left\{\left[\mathrm{Cu}\left(\mathrm{PPh}_{3}\right)_{2}(\mathrm{pCPy})\right]\left(\mathrm{BF}_{4}\right)\right\}_{\infty}(\mathbf{6})$. However, unlike mDCB, mCPy formed a cyclic trimer $\left[\mathrm{Cu}_{3}\left(\mathrm{PPh}_{3}\right)_{6}(\mathrm{mCPy})_{3}\right]\left(\mathrm{BF}_{4}\right)_{3}(\mathbf{5})$ rather than a polymer. 
Ortho and para complexes 1, 3, 4, and 6 appeared yellow under visible light and were brightly emissive in the yellow to blue-green region under $365 \mathrm{~nm}$ black light irradiation. In contrast the meta complexes $\mathbf{2}$ and $\mathbf{5}$ were both white under visible light and brightly emissive in the blue region under black light (see below).

\subsection{X-ray Structures}

\section{Solvated o-Dicyanobenzene Dimers}

It was readily apparent that compound $\mathbf{1}$ (oDCB dimer complex) was highly subject to solvent inclusion in the crystal lattice. Therefore, crystals of the solvent-free yellow powder initially precipitated from toluene were grown from $\mathrm{CH}_{2} \mathrm{Cl}_{2}, \mathrm{CHCl}_{3}, \mathrm{THF}$, and acetone solutions via liquid diffusion of ethyl ether. Compound $\mathbf{1}$ yielded a mixture of yellow and nearly colorless block crystals when grown from all solvent combinations, except acetone/ether. The distribution of solvent-free (1a) and solvent-containing (1b-1e) crystals in these experiments is summarized in Table 1. In situ photographs of these crystals under room light and $365 \mathrm{~nm}$ black light are shown in Figures 1 and S1 (supporting information). The yellow solvent-free crystals dominated when 1 was crystallized from chlorinated solvents and acetone (in the latter case 1a was the only product). Colorless solvent-containing crystals were dominant only in the case of THF solvent. Slower crystallization (e.g. in the freezer) tended to produce higher proportion of solvento crystals. In addition, allowing a mixture of the two crystal types to remain under the crystallization solvent caused slow conversion: yellow $\rightarrow$ colorless. While the yellow crystals exhibited intense yellow luminescence emission under $365 \mathrm{~nm}$ black light, the colorless crystals showed greatly diminished luminescence emission. 


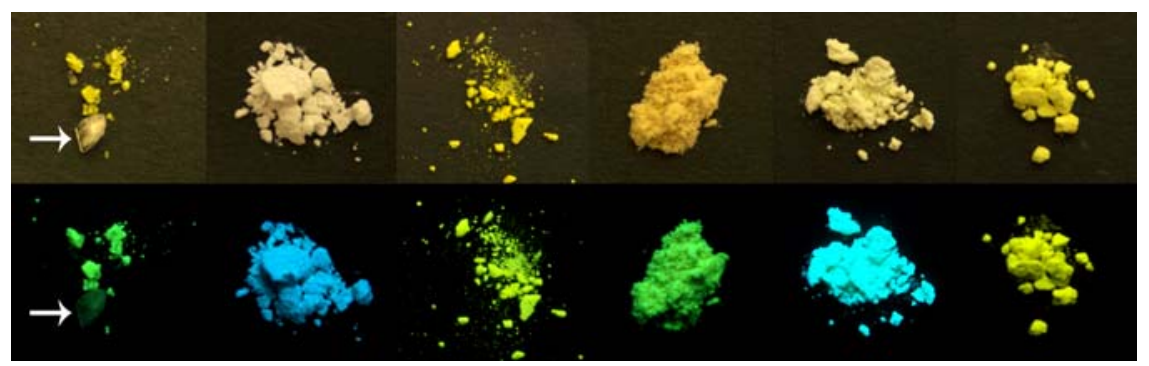

Figure 1. Photographs under room light (top) and $365 \mathrm{~nm}$ black light (bottom) of 1-6 (right to left). The arrows for $\mathbf{1}$ point out a crystal of colorless non-emissive $\mathbf{1 b}$ or $\mathbf{1 c}$ amidst yellow emissive crystals of $\mathbf{1 a}$.

The X-ray structure of the cubic yellow blocks that grew from $\mathbf{1}$ in all solvents used showed a solvent-free dimeric compound $\left[\mathrm{Cu}_{2}\left(\mathrm{PPh}_{3}\right)_{4}(\mathrm{oDCB})_{2}\right]\left(\mathrm{BF}_{4}\right)_{2}(\mathbf{1 a})$. Two $\mathrm{Cu}(\mathrm{I})$ centers are bridged by a pair of $o$-DCB ligands and capped by four $\mathrm{PPh}_{3}$ ligands to complete the distorted tetrahedral coordination sphere at each metal center (Figures 2, 3, and S2). The structure is halfindependent, being centered about a crystallographic inversion center. Fluorine positional disorder was present in $\mathrm{BF}_{4}{ }^{-}$, and was modelled over two sites. The bond lengths and angles (see Table 3) are within normal ranges for $\mathrm{Cu}(\mathrm{I})$ nitrile complexes [7]-[9],[16]. Unsurprisingly, the $\mathrm{N}-\mathrm{Cu}-\mathrm{N}$ angle is relatively small: $105.01(8)^{\circ}$, and the $\mathrm{P}-\mathrm{Cu}-\mathrm{P}$ angle relatively large: $120.94(2)^{\circ}$. Interestingly, the $\mathrm{N}-\mathrm{Cu}-\mathrm{P}$ angles spanned a very wide range: $97.71(5), 104.67(6), 108.27(6)$, and $117.47(6)^{\circ}$. At the center of the dimer is a $14-$ membered $\mathrm{Cu}_{2}(o-\mathrm{DCB})_{2}$ ring. This macrocycle is fairly planar in 1a. The copper atoms were not perfectly linear with the cyano groups, with $\mathrm{Cu}-\mathrm{N}-\mathrm{C}$ angles being $159.54(17)$ and $168.42(18)^{\circ}$. The 6-atom oDCB least-squares ring planes are nearly parallel with one another, with an interplanar angle of $0.009^{\circ}$. The DCB planes are displaced from one another by a mere $0.279 \AA$. The $\mathrm{Cu}$ atom is displaced from the DCB planes by 0.300 and $0.579 \AA$. The $\mathrm{Cu} \cdots \mathrm{Cu}$ distance is $6.276 \AA$. 


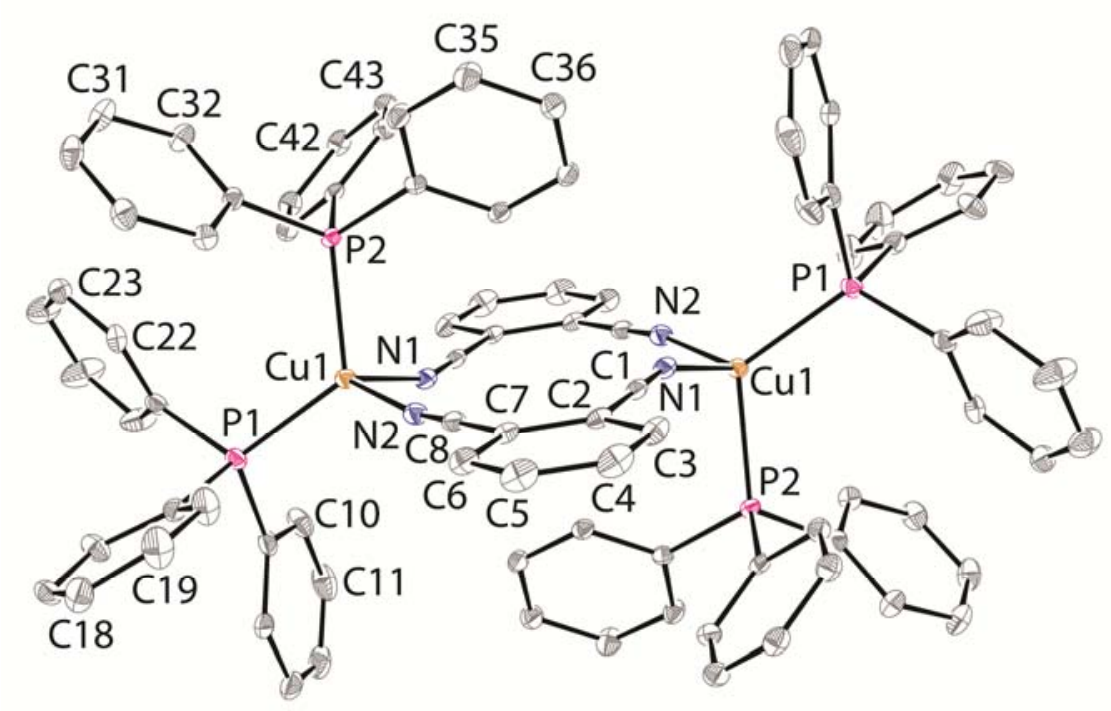

Figure 2. (A) Thermal ellipsoid (50\%) drawing of 1a. Hydrogen atoms and $\mathrm{BF}_{4}^{-}$omitted. Color key for all $\mathrm{X}$-ray structures: $\mathrm{Cu}=$ orange, $\mathrm{P}=$ pink, $\mathrm{N}=$ blue, $\mathrm{C}=$ grey.

Crystallization of $\mathbf{1}$ from $\mathrm{CH}_{2} \mathrm{Cl}_{2}$ /ether gave colorless blocks in addition to the yellow $\mathbf{1 a}$ crystals described above. Amongst these colorless blocks, two closely-related crystal compositions were identified: $\quad\left[\mathrm{Cu}_{2}\left(\mathrm{PPh}_{3}\right)_{4}(\mathrm{oDCB})_{2}\right]\left(\mathrm{BF}_{4}\right)_{2} \cdot 1 / 2 \mathrm{CH}_{2} \mathrm{Cl}_{2} \quad$ (1b) and $\left[\mathrm{Cu}_{2}\left(\mathrm{PPh}_{3}\right)_{4}(\mathrm{oDCB})_{2}\right]\left(\mathrm{BF}_{4}\right)_{2} \bullet \mathrm{CH}_{2} \mathrm{Cl}_{2}(\mathbf{1 c})$. Crystal structures were solved for both solvate dimers (see Figures 3 and S3-S6). In contrast to $\mathbf{1 a}$, the dimer unit in $\mathbf{1 b}$ is fully independent crystallographically, with two independent copper atoms. The bond lengths and angles are in the same range as those of $\mathbf{1 a}$, although the two $\mathrm{P}-\mathrm{Cu}-\mathrm{P}$ angles are somewhat more open: 122.38(3), $126.25(3)^{\circ}$. Due to the lack of molecular inversion center, the DCB planes in $\mathbf{1 b}$ are not at all coplanar, having an interplanar angle of $49.88^{\circ}$, and the macrocycle is highly puckered. The copper atoms lie between the planes defined by the DCB rings. Cul lies at positions 0.679 and $-1.093 \AA$ with respect the N1/N2 and N3/N4 DCB planes, respectively. The analogous values for $\mathrm{Cu} 2$ are -0.999 and $+0.495 \AA$. The $\mathrm{Cu} \cdots \mathrm{Cu}$ distance is $6.162 \AA$. The half $\mathrm{CH}_{2} \mathrm{Cl}_{2}$ molecule in $\mathbf{1 b}$ was centered on an inversion center. Fluorine disorder was again present in one $\mathrm{BF}_{4}^{-}$ion, and was modelled over two positions. 


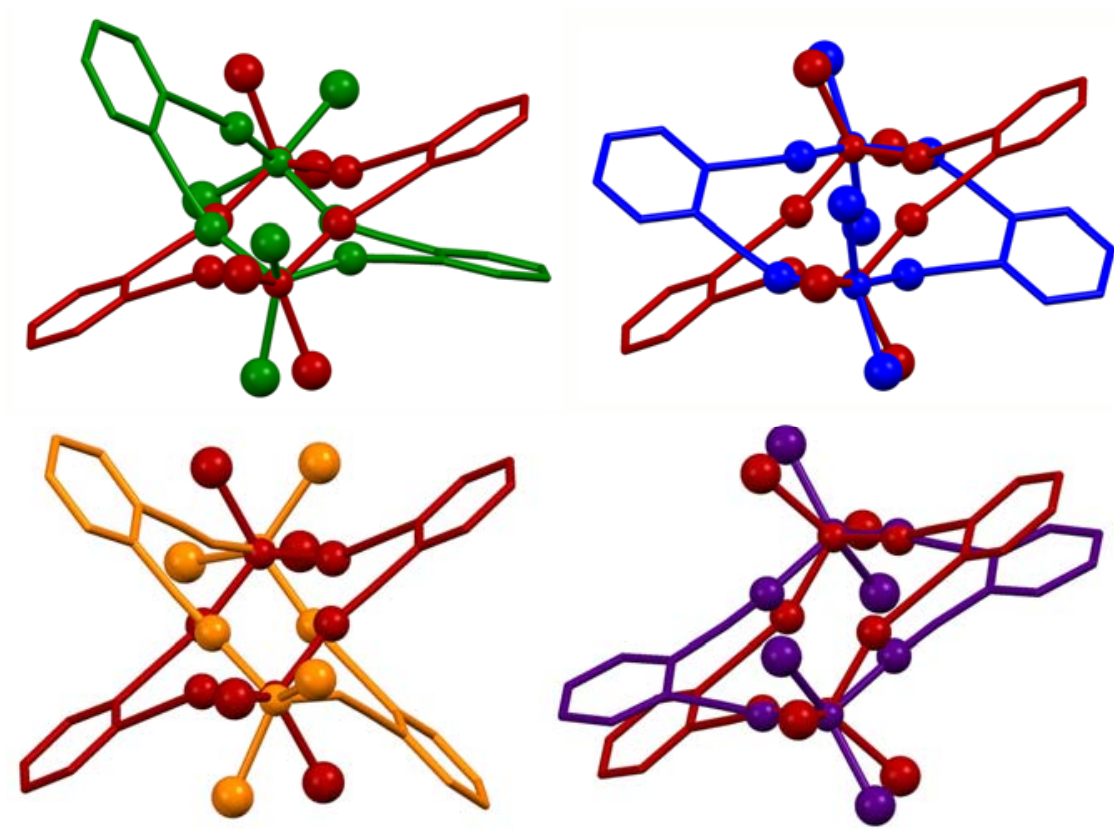

Figure 3. Clockwise from upper left, overlays of 1a (red) with $\mathbf{1 b}$ (green), 1c (blue), 1d (orange), and $1 \mathrm{e}$ (purple). $\mathrm{Cu}, \mathrm{N}$, and $\mathrm{P}$ atoms shown as ball and stick; $\mathrm{C}$ atoms shown as wireframe. Hydrogen atoms, phenyl groups, solvent molecules, and $\mathrm{BF}_{4}{ }^{-}$anions are omitted.

Similar to 1a, but in contrast to $\mathbf{1 b}$, the dimer in solvate complex $\mathbf{1 c}$ was centered on an inversion site located at the center of the 14-membered ring. As for $\mathbf{1 b}$, the $\mathrm{CH}_{2} \mathrm{Cl}_{2}$ molecule in $\mathbf{1 c}$ lay on an inversion center postion. Thus, both the dimer unit and the solvent in 1c are halfindependent. The bond lengths and angles are relatively similar to those of $\mathbf{1 a}$ and $\mathbf{1 b}$; however, the $\mathrm{N}-\mathrm{Cu}-\mathrm{N}$ is rather small and $\mathrm{P}-\mathrm{Cu}-\mathrm{P}$ is rather large: $95.46(7)$ and $123.86(2)^{\circ}$, respectively. The oDCB ring itself is slightly less planar that those in $\mathbf{1 a}$ or $\mathbf{1 b}$, but as is the case in 1a, the two DCB rings in the dimer are parallel (interplanar angle $=0^{\circ}$ ), being displaced from one another by a distance of $0.403 \AA$. The copper atoms are elevated above the DCB planes by 0.804 and 1.207 $\AA$. The $\mathrm{Cu} \cdots \mathrm{Cu}$ distance is $6.486 \AA$. A face-to-face intramolecular $\pi$-stacking arrangement (centroid *centroid distance $=4.081 \AA$ ) is noted between phenyl rings attached to P1 (C9-C14) and $\mathrm{P} 2(\mathrm{C} 39-\mathrm{C} 44)$ at a common $\mathrm{Cu} 1$ atom. 
The colorless crystals that formed in $\mathrm{CHCl}_{3} /$ ether along with 1a proved to be $\left[\mathrm{Cu}_{2}\left(\mathrm{PPh}_{3}\right)_{4}(\mathrm{oDCB})_{2}\right]\left(\mathrm{BF}_{4}\right)_{2} \cdot 2 \mathrm{CHCl}_{3} \cdot \mathrm{H}_{2} \mathrm{O}(\mathbf{1 d})$. Crystallization of $\mathbf{1}$ from THF produced mostly colorless crystals, which proved to be $\left[\mathrm{Cu}_{2}\left(\mathrm{PPh}_{3}\right)_{4}(\mathrm{ODCB})_{2}\right]\left(\mathrm{BF}_{4}\right)_{2} \cdot 2 \mathrm{THF}(\mathbf{1 e})$ (see Figures 3 and S7-S10). Chloroform/water solvate dimer $\mathbf{1 d}$ is (along with $\mathbf{1 b}$ ) one of two oDCB dimers herein for which the macrocycle lacks inversion symmetry. It also shows an interesting twist in the macrocycle, causing the two antiparallel oDCB ring planes to lie at an angle of $18.37^{\circ}$ to one another. Both copper atoms lie within the cleft between these planes at distances of 0.237 and $0.576 \AA$ for $\mathrm{Cu} 1 \cdots$ plane and of 0.522 and $0.737 \AA$ for $\mathrm{Cu} 2 \cdots$ plane. The five other crystallographically independent species in the structure: two $\mathrm{CHCl}_{3}$ molecules, two $\mathrm{BF}_{4}^{-}$ions, and a $\mathrm{H}_{2} \mathrm{O}$ molecules were all fully ordered, and no intermolecular interactions were noted between any of the entities present.

Like 1a and 1c, the half-independent structure of 1e featured an inversion site at the center of the macrocycle. The THF molecule was fully independent and ordered; the anion was also fully ordered. The bond lengths and angles are quite similar to those of the other structures of 1. The distance between the two oDCB rings is $0.638 \AA$ and the interplanar angle between them is $0^{\circ}$. In this case the cyano groups are somewhat out of plane from the DCB rings. One of the $\mathrm{C} \equiv \mathrm{N}-\mathrm{Cu}$ groups lies above the DCB plane by $0.181,0.354$, and $0.143 \AA$ for $\mathrm{C}, \mathrm{N}$, and $\mathrm{Cu}$ respectively, while the other $\mathrm{C} \equiv \mathrm{N}-\mathrm{Cu}$ arm is displaced downward by $0.197,0.434$, and $0.780 \AA$. The $\mathrm{Cu}^{\cdots} \mathrm{Cu}$ distance is $6.452 \AA$.

Formation of $\left[\mathrm{Cu}\left(\mathrm{PPh}_{3}\right)_{2}\right]^{+}$dimers by dicyanoorganic compounds has been seen in four previous cases [7b],[7d],[17]. The bridging ligands involved have been short, rigid, anionic linkers, such as dicyanamide, substituted dicyanomethanides and pentacyanocyclopentadienide. Similar to the various solvates of $\mathbf{1}$ reported herein, these literature dimers show $\mathrm{N}-\mathrm{Cu}-\mathrm{N}$ in the range of $92.8-104.1^{\circ}$, and $\mathrm{P}-\mathrm{Cu}-\mathrm{P}$ in the range of $124.1-126.6^{\circ}$. However, literature $\mathrm{Cu} \cdots \mathrm{Cu}$ values in the range of $6.76-6.98 \AA$ are somewhat longer than those seen for oDCB $(6.162-6.566$ $\AA$ ). This is probably the result of the more rigid ligands used in the literature structures. 
$m$ - and p-Dicyanobenzene Polymers

Crystallization of $\left[\mathrm{Cu}\left(\mathrm{PPh}_{3}\right)_{2}(\mathrm{mDCB})\right] \mathrm{BF}_{4}(2)$ from either $\mathrm{CH}_{2} \mathrm{Cl}_{2}$ or $\mathrm{CHCl}_{3}$ afforded colorless prism crystals. These solved by X-ray diffraction as a solvent-free zigzag polymer (Figures 4 and S11). The crystallographic repeat unit consists of $\left[\mathrm{Cu}\left(\mathrm{PPh}_{3}\right)_{2}(\mathrm{mDCB})\right]^{+}$and $\mathrm{BF}_{4}^{-}$ units. Expansion of the structure along a 21 axis produces an mDCB-bridged polymer. The polymer represents a hypothetical ring-opening of the dimers seen in 1a-1e. The ${ }^{\cdot} \mathrm{Cu}-\mathrm{DCB}-\mathrm{Cu}-\mathrm{DCB} \cdots$ backbone lies very nearly within a plane, but the slight bending of the $\mathrm{Cu}-\mathrm{N} \equiv \mathrm{C}$ angles $\left(169.49(19)\right.$ and $\left.161.67(18)^{\circ}\right)$ produce a helical arrangement when viewed along the backbone (Figure S11). Adjacent mDCB least-squares planes lie at $6.84^{\circ}$ angles to one another. The two $\mathrm{Cu}(\mathrm{I})$ centers bonded to a DCB ligand lie $0.203 \AA$ above and $0.683 \AA$ below the plane defined by the ligand ring. Adjacent chains experience a face-to-face $\pi$-stacking interaction (centroid *centroid distance $=3.998 \AA$ ) between $\mathrm{mDCB}(\mathrm{C} 2-\mathrm{C} 7)$ and a phosphane phenyl (C21-C26). The $\mathrm{P}-\mathrm{Cu}-\mathrm{P}$ angle is relatively large: $128.50(2)^{\circ}$. The $\mathrm{Cu} \cdots \mathrm{Cu}$ distances along the chain are $10.523 \AA$, and the $\mathrm{Cu}^{\cdots} \mathrm{Cu}^{\cdots} \mathrm{Cu}$ angle is $104.03^{\circ}$. The $\mathrm{BF}_{4}{ }^{-}$counterions sit in the vacant spaces created by the zigzag shape of the polymer.

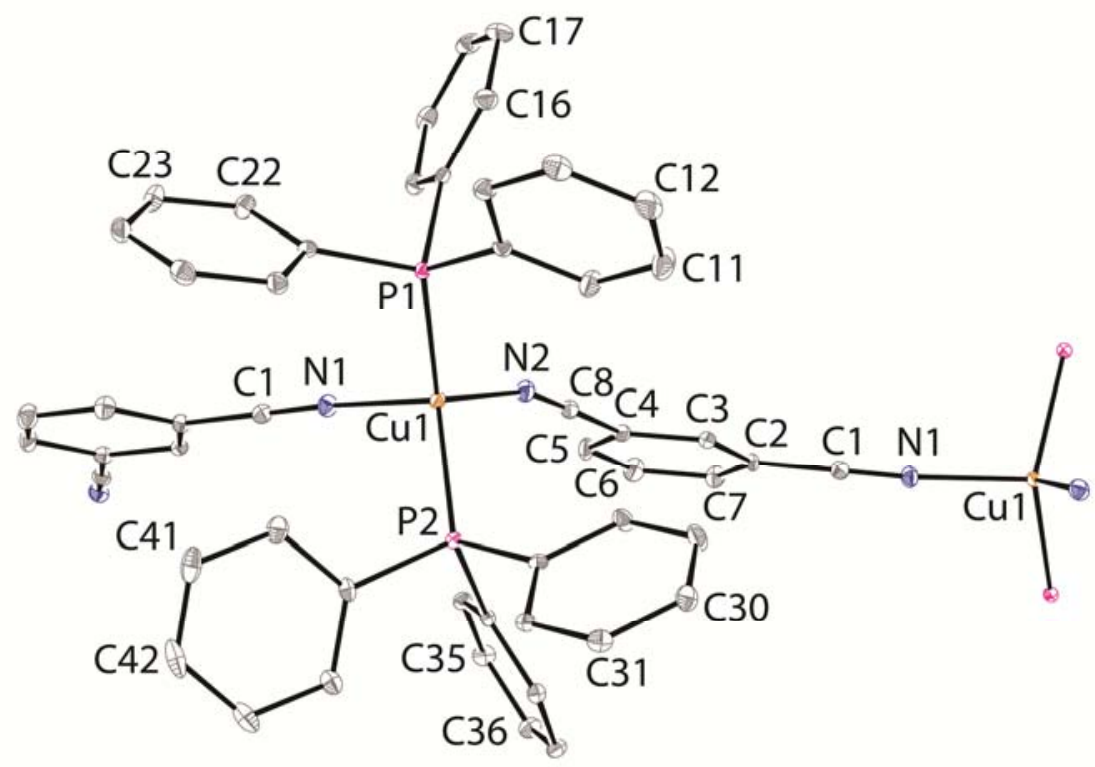


Figure 4. Thermal ellipsoid (50\%) drawing of the crystallographic repeat unit in 2 . Hydrogen atoms omitted.

Crystallization of $\left[\mathrm{Cu}\left(\mathrm{PPh}_{3}\right)_{2}(\mathrm{pDCB})\right] \mathrm{BF}_{4}(3)$ from $\mathrm{CH}_{2} \mathrm{Cl}_{2}$ produced yellow needle and block crystals. Two polymorphs with nearly identical structures were identified: monoclinic 3a (see Figures 5, 6, and S12) and triclinic 3b (see Figures 6, S13 and S14). Both structures show a zigzag polymer arrangement with one molecule of $\mathrm{CH}_{2} \mathrm{Cl}_{2}$ per monomer unit in the lattice. An overlay of the polymorphs is shown in Figure 6. In both polymorphs, the crystallographic repeat unit contains a portion of the cationic polymer two monomer units in length, two $\mathrm{BF}_{4}{ }^{-}$ions (one of which is disordered) and two positionally disordered $\mathrm{CH}_{2} \mathrm{Cl}_{2}$ molecules. As is the case with $\mathbf{2}$, the $\mathrm{BF}_{4}^{-}$ions sit within the angles of the zigzag chain. The solvent molecules lie between the polymer chains. The bond lengths and angles around copper are similar to the others seen herein. The $\mathrm{Cu}{ }^{\cdots} \mathrm{Cu}$ distances along the chain are $11.398 \AA$ and $11.786 \AA$, and all $\mathrm{Cu}{ }^{\cdots}{ }^{*} \mathrm{Cu}{ }^{\cdots} \mathrm{Cu}$ angles are $97.32^{\circ}$. In contrast to $\mathbf{2}$, the polymer chains in $\mathbf{3 a}$ and $\mathbf{3 b}$ do not lie neatly within planes. In both polymorphs, one of the pDCB ligands shows unusually large $\mathrm{C} \equiv \mathrm{N}-\mathrm{Cu}$ bending: $140.7(3)$, $148.5(3)^{\circ}$ in $\mathbf{3 a}$ and $140.32(18), 149.58(19)^{\circ}$ in $\mathbf{3 b}$. This produces a slight "figure- 8 " type helicity along the polymer chains (see Figures S12 and S14). The pairs of planes defined by the two $\mathrm{pDCB}$ rings in $\mathbf{3 a}$ and $\mathbf{3 b}$ lie at angles of 9.35 and $6.38^{\circ}$ to one other. 


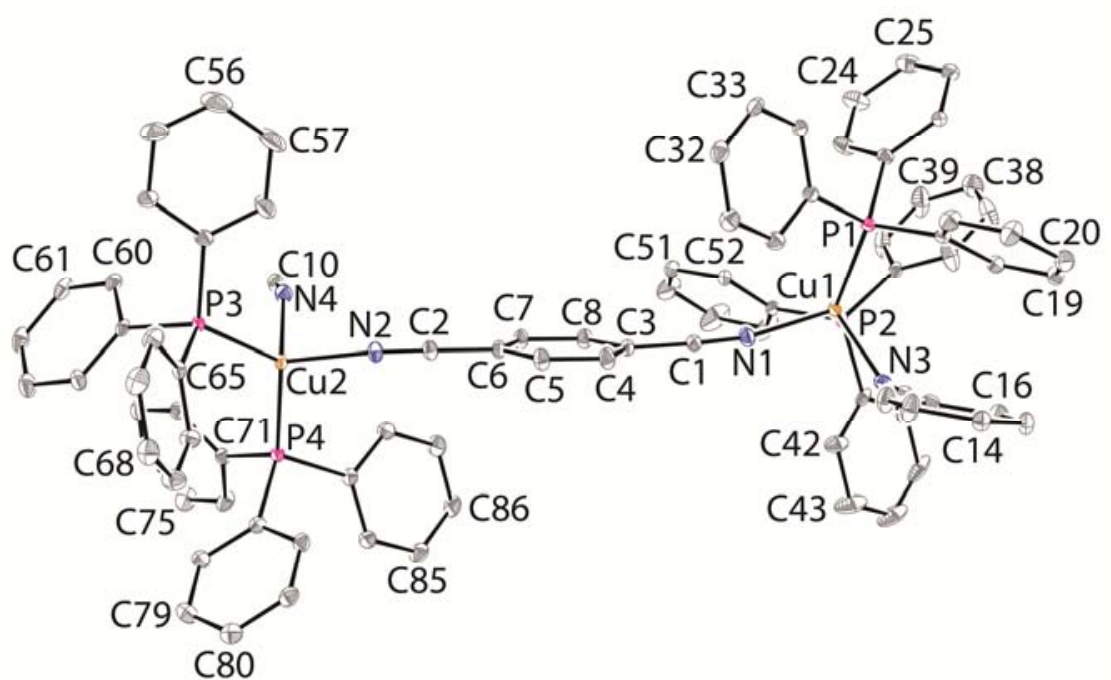

Figure 5. Thermal ellipsoid (50\%) drawing of the crystallographic repeat unit in $\mathbf{3 a} . \mathrm{CH}_{2} \mathrm{Cl}_{2}$ and $\mathrm{BF}_{4}^{-}$omitted.

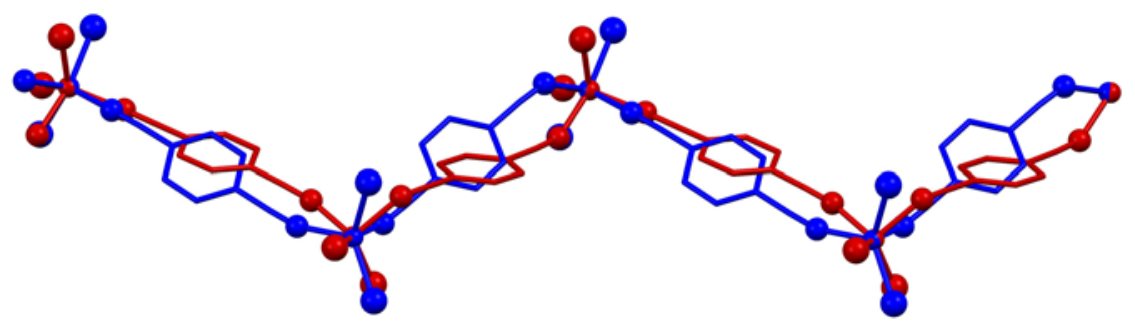

Figure 6. Overlay of $\mathbf{3 a}$ (red) and $\mathbf{3 b}$ (blue). $\mathrm{Cu}, \mathrm{N}$, and $\mathrm{P}$ atoms shown as ball and stick; $\mathrm{C}$ atoms shown as wireframe. Hydrogen atoms, phenyl groups, $\mathrm{CH}_{2} \mathrm{Cl}_{2}$, and $\mathrm{BF}_{4}^{-}$are omitted.

\section{Cyanopyridine Complexes}

Crystallization of undried oCPy complex 4 (prepared in toluene) from $\mathrm{CH}_{2} \mathrm{Cl}_{2}$ yielded a dimeric solvate structure (4a), related to $\mathbf{2 a}-\mathbf{2 c}$ (Figures 7 and S15). The dimer, centered about an inversion center, is half independent. A single crystallographically independent molecule of toluene is present. Thus two toluene molecules and one copper dimer are present in the triclinic unit cell. The toluene molecule is disordered over two non-overlapping positions. However, the $\mathrm{BF}_{4}^{-}$is ordered. Likewise, the oCPy ligand is ordered, providing a contrast to the mCPy and pCPy ligands in $\mathbf{5}$ and 6a (see below). The $\mathrm{Cu}$ atoms in the dimer are separated from one another 
across the 10-membered ring by $5.494 \AA$, significantly shorter than those in $\mathbf{1 a}-\mathbf{1 c}$ due to the more compact ligand. The least squares planes defined by the two oCPy ligands are perfectly parallel and these planes are separated by $0.059 \AA$. The unique $\mathrm{Cu}$ atom lies $0.325 \AA$ and $0.385 \AA$ above the oCpy planes. The $\mathrm{Cu}-\mathrm{N}_{\mathrm{Py}}$ distance is significantly greater than $\mathrm{Cu}-\mathrm{NC}$, as is commonly the case in $\mathrm{Cu}(\mathrm{I})$ complexes. Interestingly, both the $\mathrm{N}-\mathrm{Cu}-\mathrm{N}$ and $\mathrm{P}-\mathrm{Cu}-\mathrm{P}$ angles are very large: $107.02(6)^{\circ}$ and $130.763(19)^{\circ}$, respectively. The former is, no doubt, the result of the rigid macrocyclic ring based on the fixed angle between the cyano group and $\mathrm{N}_{\mathrm{Py}}$ in the ligand.

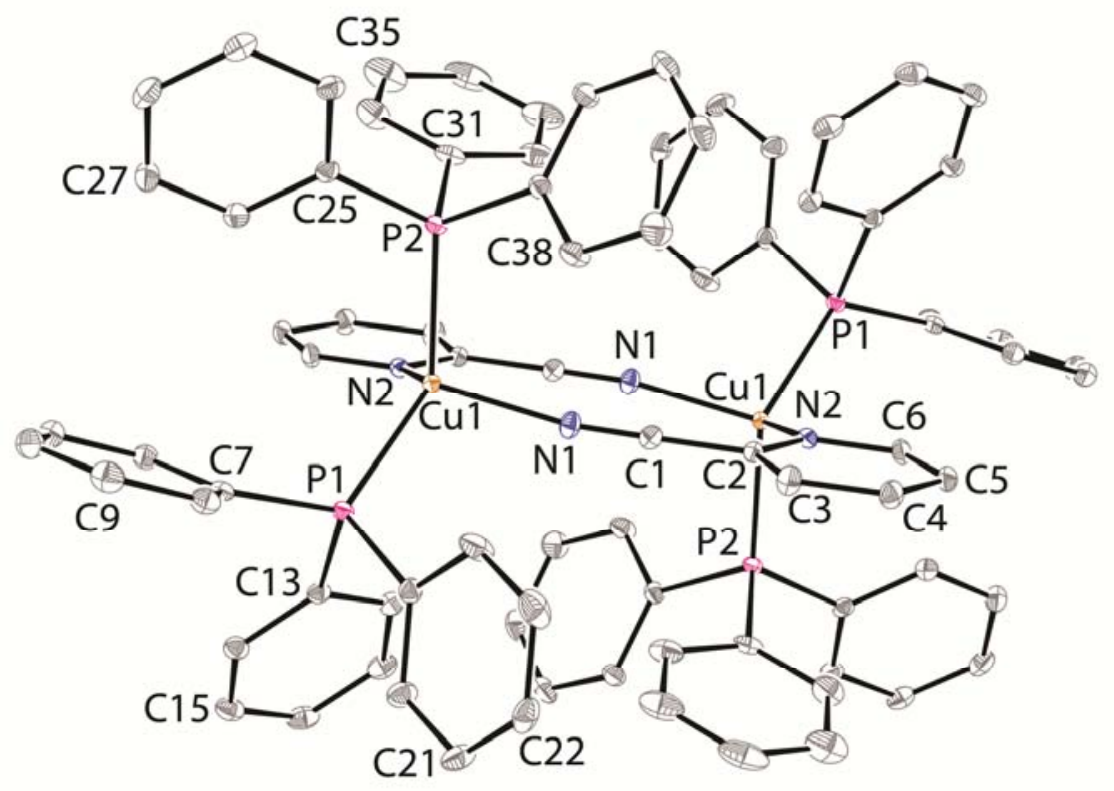

Figure 7. Thermal ellipsoid (50\%) drawing of 4a. Hydrogen atoms, $\mathrm{BF}_{4}^{-}$, and toluene molecules omitted.

The mCPy complex (5) yielded a solvent-free trimeric structure, whether crystallized from $\mathrm{CHCl}_{3}$ or $\mathrm{CH}_{2} \mathrm{Cl}_{2}$ (Figures $8, \mathrm{~S} 16$, and $\mathrm{S} 17$ ). The space group is trigonal $R 3 \mathrm{c}$. The trimeric structure is $1 / 3$ independent, with a single crystallographically independent $\mathrm{Cu}$ atom and bridging mCPy. Three $1 / 3$ independent $\mathrm{BF}_{4}^{-}$ions (one positionally disordered) are present, each lying on a three-fold axis and centered along the $c$-axis coincident with the center of the $\mathrm{Cu}$ trimer. The mCPy ligands show disorder (see Figures S16 and S17) between cyano and pyridine bonding at 
$\mathrm{Cu}$ with $\mathrm{N}_{\mathrm{Py}}$ and $\mathrm{N}_{\text {cyano }}$ lying in nearly identical locations. The mCPy orientation shown in Figure 8 was preferred over the other orientation by $69: 31$. The two ligand planes in the disordered positions lie at a $24.35^{\circ}$ angle to one another. The pyridine rings are canted slightly out of the $\mathrm{Cu}_{3}$ ring plane $\left(13.71^{\circ}\right)$, forming a shallow bowl-like arrangement around the three-fold axis. These $\mathrm{Cu}_{3}$ ring planes are stacked parallel to the crystallographic $c$-axis with anions located vertically between them. The $\mathrm{Cu}^{\cdots \cdots} \mathrm{Cu}$ distance across the triangular molecular core of a trimer is $8.607 \AA$. Ring strain in the cyclic trimer is evident in the $\mathrm{C} 2-\mathrm{C} 1-\mathrm{N} 2$ angle of $166.7(16)^{\circ}$, contrasting with the other $\mathrm{C}_{\text {ring }}-\mathrm{C} \equiv \mathrm{N}$ angles seen herein, none of which are more than $5.5^{\circ}$ from linearity.

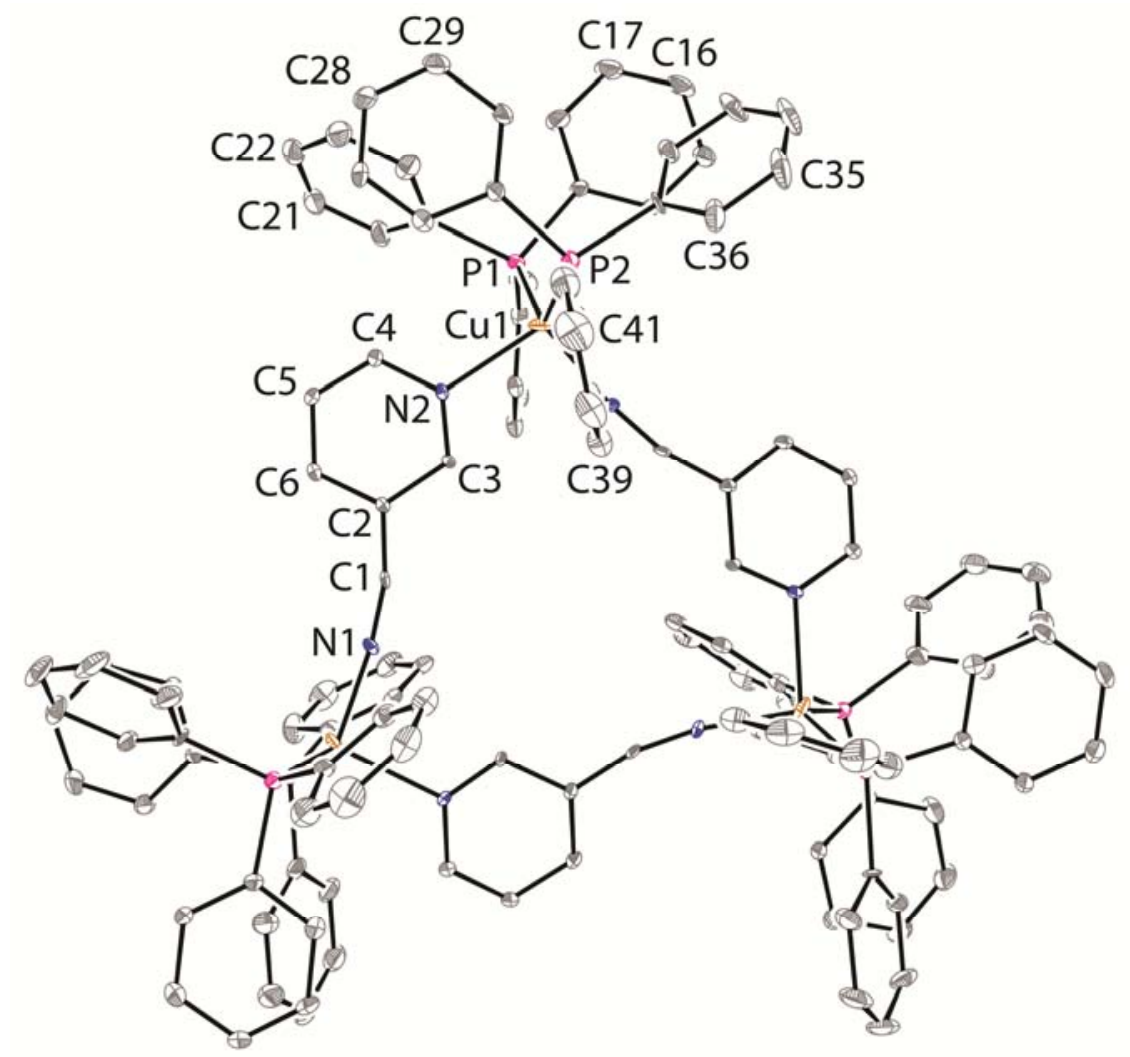

Figure 8 . Thermal ellipsoid (50\%) drawing of $\mathbf{5}$. Hydrogen atoms, minor oCPy position, and $\mathrm{BF}_{4}{ }^{-}$ omitted.

The pCPy complex (6) proved to be a polymer (see Figures 9, S18, and S19), crystallizing from acetone as a hemi-acetone solvate (6a) in the monoclinic space group $C 2 / \mathrm{c}$. In 
contrast to both polymorphs of the pDCB polymer (3), the repeat unit in $\mathbf{6 a}$ consisted of a single monomer unit: $\left[\mathrm{Cu}\left(\mathrm{PPh}_{3}\right)_{2}(\mathrm{pCPy})\right] \mathrm{BF}_{4}$, along with half a molecule of acetone. As was the case for the mCPy ligand in trimer 5, the pCPy ligand adopted two disordered positions with nearly overlapping $\mathrm{N}_{\mathrm{Py}}$ and $\mathrm{N}_{\text {cyano' }}$ positions. The occupancies of the positions were slightly unequal (55.5:45.5). In addition, the single $\mathrm{BF}_{4}^{-}$ion was disordered over two positions. The two ligand planes created by the disordered pCPy positions lie at an angle of $22.14^{\circ}$ with respect to one another. Using the least-squares plane from the major ligand plane position, the $\mathrm{Cu}$ atom shows a step behavior along the chain, lying more nearly in-plane in one direction $(0.205 \AA)$ than in the other $(0.636 \AA)$. The $\mathrm{Cu}$ atom shows nearly equidistant displacement with respect to the minor of the two disordered ligand planes (displacement $=0.404$ and $0.444 \AA$ in opposite directions along the chain). The $\mathrm{Cu}^{\cdots} \mathrm{Cu}$ distances along the chain are $9.414 \AA$, and the $\mathrm{Cu}^{\cdots} \mathrm{Cu}^{\cdots} \mathrm{Cu}$ angles are $102.45^{\circ}$. As was noted for the other polymers herein, the polymer chain is slightly helical. Bond lengths and angles in $\mathbf{6}$ are unremarkable, except for the exceptionally large $\mathrm{P}-\mathrm{Cu}-\mathrm{P}$ of 132.34(7), the largest such value seen in this study.

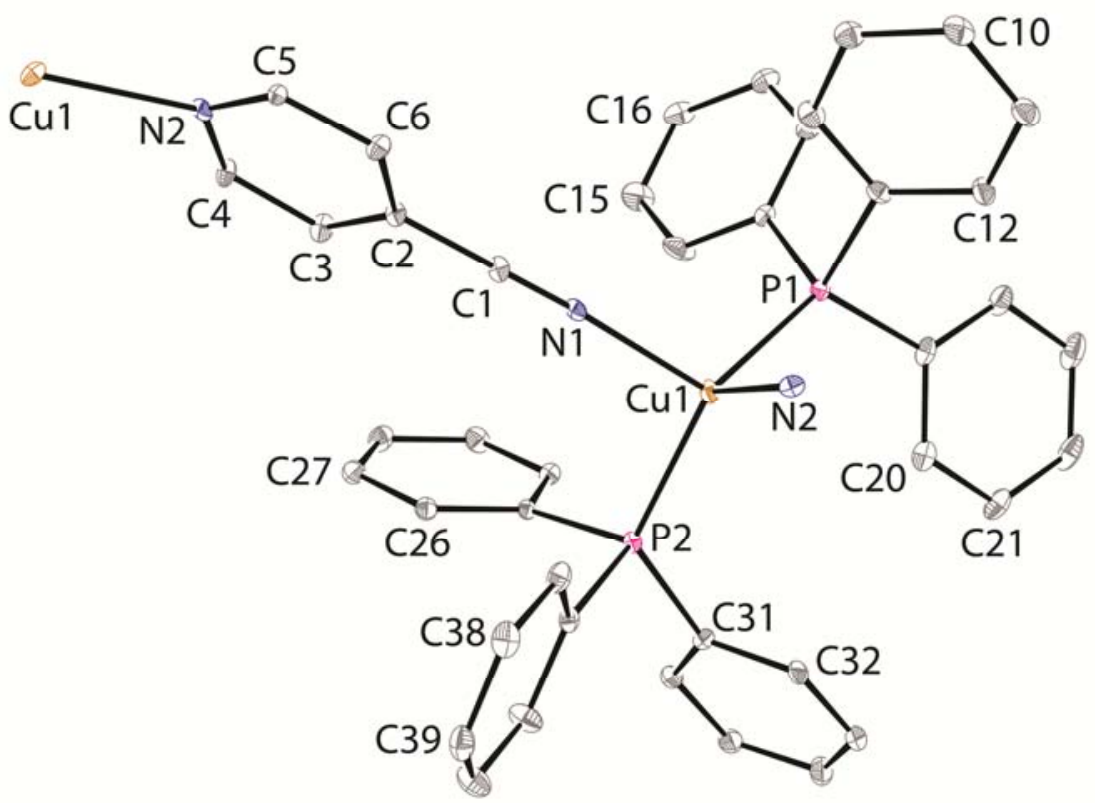

Figure 9. Thermal ellipsoid (50\%) drawing of the crystallographic repeat unit in 6a. Hydrogen atoms, minor $\mathrm{pCPy}$ position, acetone, and $\mathrm{BF}_{4}{ }^{-}$omitted. 


\subsection{Photophysics}

Solid state luminescence studies show moderate to intense response for compounds $\mathbf{1 - 6}$, as shown in Table 4, Figures 10 and 11 (298 K) and Figures S26-S31 (77 K). All samples were vacuum dried and were therefore solvent-free. Excitation spectra reveal that all complexes excite in the UV to near visible range (340-400 nm), with subsequent emission in the visible region. The meta complexes $\mathbf{2}$ and $\mathbf{5}$ are excited at somewhat higher energies than are complexes 1, 3, 4, and 6. Peak excitation values lying farther into the UV for $\mathbf{2}$ and $\mathbf{5}$ correlate to the white color of these complexes under visible light, in contrast to the yellow color of complexes $\mathbf{1}, \mathbf{3}, \mathbf{4}$, and $\mathbf{6}$. In addition the meta ligand complexes $\mathbf{2}$ and $\mathbf{5}$ show emission of varying intensities in the blue region (485 $\mathrm{nm}$ and $493 \mathrm{~nm}$ ), while the ortho and para complexes show moderate to intense emission in the green region (509-546 nm). mDCB polymer complex 2 shows the largest Stokes shift amongst the three DCB complexes and the shortest emission wavelength amongst all complexes: $7,870 \mathrm{~cm}^{-1}$ and $485 \mathrm{~nm}$, respectively. Interestingly, complex 5, the corresponding mCPy species, also exhibits the shortest emission wavelength amongst CPy species.

Comparing the DCB complexes to their CPy analogs, it will be noted that in all cases the room temperature Stokes shifts are much larger for the CPy complexes. Interestingly, oDCB and oCPy both yield emission at a wavelength of $518 \mathrm{~nm}$. Nevertheless, the stark difference in Stokes shift between oDCB and oCPy complexes is still seen. The meta and para ligands reveal a red shift as DCB ligands are replaced with CPy. While solid state quantum yields were not determined, emission intensity differences amongst the complexes were apparent. Replacement of DCB with CPy results in a drastic decrease in emission intensity for the meta and para complexes. Conversely, the ortho species (1 and 4) show an increase in emission intensity when the oDCB ligand is replaced with oCPy. As a result, complex 4 clearly shows the highest emission intensity of the CPy species, while $\mathbf{2}$ and $\mathbf{3}$ show the stronger emission intensities amongst the DCB species. 


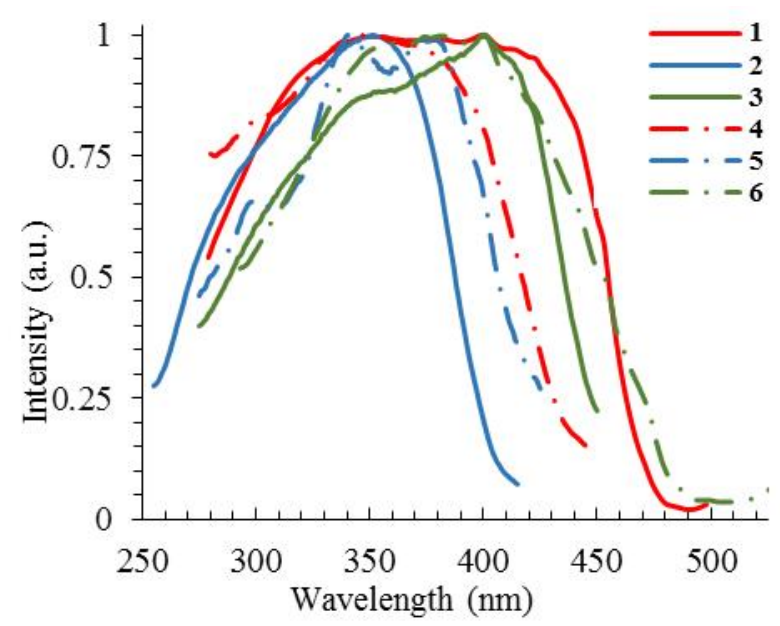

Figure 10. Solid state luminescence excitation spectra of 1-6 at $298 \mathrm{~K}$. Emission monitored at $\lambda_{\max }$ for each complex (see Table 4).

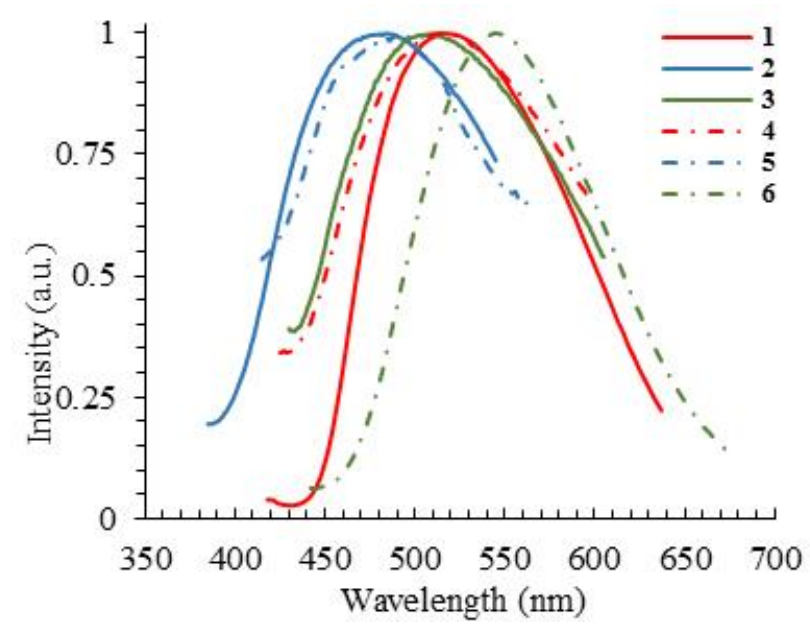

Figure 11. Solid state luminescence emission spectra of 1-6 at $298 \mathrm{~K}$. Excitation carried out at $\lambda_{\max }$ for each complex (see Table 4).

Metal-to-ligand charge transfer (MLCT) has been identified as underlying the intense luminescence noted in previous studies of pyridine-type diimine $\mathrm{Cu}(\mathrm{I})$ complexes [5],[18]. In these previous cases, the Stokes shifts have been relatively large, in the range of 9,000-11,000 $\mathrm{cm}^{-1}$. Such shifts are suggestive of large excited state distortions. However, we know of no such photophysical results in the literature for cyanoaromatic $\mathrm{Cu}(\mathrm{I})$ complexes. Thus, it is of interest to 
examine the trend moving from polymers constructed from aromatic diimines such as pyrazine (Pyz) or 4,4'-dipyridyl (Bpy) to those constructed from dicyanoaromatics such as pDCB:

$$
\left\{\left[\mathrm{Cu}\left(\mathrm{PPh}_{3}\right)_{2}(\mathrm{Pyz})\right] \mathrm{BF}_{4}\right\}_{\infty} \rightarrow\left\{\left[\mathrm{Cu}\left(\mathrm{PPh}_{3}\right)_{2}(\mathrm{pCPy})\right] \mathrm{BF}_{4}\right\}_{\infty}(\mathbf{6}) \rightarrow\left\{\left[\mathrm{Cu}\left(\mathrm{PPh}_{3}\right)_{2}(\mathrm{pDCB})\right] \mathrm{BF}_{4}\right\}_{\infty}(\mathbf{3})
$$

We previously identified Stokes shift values of $10,240 \mathrm{~cm}^{-1}$ for $\left\{\left[\mathrm{Cu}\left(\mathrm{PPh}_{3}\right)_{2}(\mathrm{Pyz})\right] \mathrm{BF}_{4}\right\}_{\infty}$ and $12,160 \mathrm{~cm}^{-1}$ for $\left\{\left[\mathrm{Cu}\left(\mathrm{PPh}_{3}\right)_{2}(\mathrm{Bpy})\right] \mathrm{BF}_{4}\right\}_{\infty}$, although these particular polymers showed weak quantum efficiencies of 0.07 [5]. In the present work, the dicyanoaromatic complexes $\mathbf{1}$ and $\mathbf{3}$ showed remarkably small Stokes shifts in the range of 5350 and $5820 \mathrm{~cm}^{-1}$, while meta complex 2 showed a moderate value of $7870 \mathrm{~cm}^{-1}$. The larger Stokes shift and high intensity retention of complex 2 might indicate a resistance to quenching behavior connected to $\pi$-stacking interactions and ion pairing. In any case, the relatively small shifts observed for the DCB species suggest that the excited state distortions in the $\mathrm{M}-\mathrm{N} \equiv \mathrm{CR}$ complexes are more modest than those of $\mathrm{M}-$ pyridine type species. Alternatively, large-shift MLCT might be of lesser importance in the cyano complexes, leaving metal centered (MC) $d \rightarrow p$ transitions as the dominant behavior. The larger Stokes shifts $\left(>9,000 \mathrm{~cm}^{-1}\right.$ for $\mathbf{4}$ and $\mathbf{5}$ and $8,000 \mathrm{~cm}^{-1}$ for $\left.\mathbf{6}\right)$ observed for the CPy species are consistent with the presence of pyridine-type nitrogen coordination as seen in previous studies. Further investigation would be required to determine to what extent these shifts are indicative of MLCT and/or MC d $\rightarrow$ p behavior.

\section{Conclusions}

Ternary mixtures of $\left[\mathrm{Cu}(\mathrm{NCMe})_{4}\right] \mathrm{BF}_{4}, 2 \mathrm{PPh}_{3}$ and $o-, m-$, or $p$-DCB, or $o-, m-$, or $p$-CPy undergo self-assembly reactions to form oligomeric complexes $\left[\mathrm{Cu}_{n}\left(\mathrm{PPh}_{3}\right)_{2 n}(\mathrm{DCB} / \mathrm{CPy})_{n}\right]\left(\mathrm{BF}_{4}\right)_{n}$. The oligomer number $(n)$ value is 2 (dimer) for oDCB and oCPy, 3 (trimer) for $\mathrm{mCPy}$, and $\infty$ (polymer) for $\mathrm{mDCB}, \mathrm{pDCB}$, and $\mathrm{pCPy}$. While solvent inclusion structures are seen for $\mathrm{pDCB}$ (2 polymorphs with $\mathrm{CH}_{2} \mathrm{Cl}_{2}$ ), oCPy (toluene), and pCPy (acetone), the oDCB dimer complex is particularly apt to form solvates. Complexes of the oDCB dimer with $1 / 2 \mathrm{CH}_{2} \mathrm{Cl}_{2}, 1 \mathrm{CH}_{2} \mathrm{Cl}_{2}, 2$ $\mathrm{CHCl}_{3}$ and $1 \mathrm{H}_{2} \mathrm{O}$, and 2 THF molecules per dimer have been characterized. Dimer complexes of 
oDCB exhibit a degree of structural flexibility in the central macrocyclic ring. Complexes of mCPy and pCPy show orientational disorder in the ligand. Polymeric complexes show chain helicity. All complexes are photoluminescent, undergoing excitation in the near UV and emitting in the blue (meta complexes) or green regions. Relatively small Stokes shifts for dicyanoaromatic complexes suggests that such ligands experience less excited state distortion than do pyridine, or mixed cyano/pyridine ligands in copper(I) complexes.

Acknowledgement. We are indebted to NSF (CHE-0443345) and the College of William and Mary for the purchase of the X-ray equipment.

\section{References}

[1] (a) K. Tsuge, Chem. Lett. 42204 (2013). (b) M. Knorr, F. Guyon, In Macromolecules Containing Metal and Metal-Like Elements, vol. 10, ed. by A.S. Abd-El-Aziz, C.E. Carraher, P.D. Harvey, C.U. Pittman, M. Zeldin, (Wiley, New York, 2010) pp. 89-158. (c) P.D. Harvey, M. Knorr Macromol. Rapid Commun. 31 (2010) 808. (d) M. Vitale, P.C. Ford, Coord. Chem. Rev. 219-221 (2001) 3. (e) P.C. Ford, E. Cariati, J. Bourassa, Chem. Rev. 99 (1999) 3625.

[2] (a) C. Bizzarri, C. Strabler, J. Prock, B. Trettenbrein, M. Ruggenthaler, C.-H. Yang, F. Polo, A. Iordache, P. Brüggeller, L. de Cola, Inorg. Chem. 53 (2014) 10944. (b) F. Wei, J. Qiu, X. Liu, J. Wang, H. Wei, Z. Wang, Z. Liu, Z. Bian, Z. Lu, Y. Zhaod, C. Huang, J. Mater. Chem. C 2 (2014) 6333. (c) D. Volz, D.M. Zink, T. Bocksrocker, J. Friedrichs, M. Nieger, T. Baumann, U. Lemmer, S. Bräse, Chem. Mater. 25 (2013) 3414. (d) S. Igawa, M. Hashimoto, I. Kawata, M. Yashima, M. Hoshinoa, M. Osawa J. Mater. Chem. C 1 (2013) 542. (e) R.D. Costa, D. Tordera, E. Ort, H.J. Bolink, J. Schönle, S. Graber, C.E. 
Housecroft, E.C. Constable, J.A. Zampese J. Mater. Chem. 21 (2011) 16108. (f) J.C. Deaton, S.C. Switalski, D.Y. Kondakov, R.H. Young, T.D. Pawlik, D.J. Giesen, S.B. Harkins, A.J.M. Miller, S.F. Mickenberg, J.C. Peters, J. Am. Chem. Soc. 13 (2010) 9499. (g) L. Zhang, B. Li, Z. Su, J. Phys. Chem. C 113 (2009) 13968.

[3] (a) P.M. Graham, R.D. Pike, M. Sabat, R.D. Bailey W.T. Pennington, Inorg. Chem. 39 (2000) 5121. (b) M.D. Dembo, L.E. Dunaway, J.S. Jones, E.A. Lepekhina, S.M. McCullough, J.L. Ming, X. Li, F. Baril-Robert, H.H. Patterson, C.A. Bayse, R.D. Pike, Inorg. Chim. Acta 364 (2010) 102. (c) K.M. Miller, S.M. McCullough, E.A. Lepekhina, I.J. Thibau, R.D. Pike, X. Li, J.P. Killarney, H.H. Patterson, Inorg. Chem. 50 (2011) 7249.

[4] A. Mukherjee, R. Chakrabarty, G.K. Patra, Inorg. Chem. Commun. 12 (2009) 1227. Y.-F. Hsu, C.-H. Lin, J.-D. Chen, J.-C. Wang, Cryst. Growth Des. 8 (2008) 1094. L.R. MacGillivray, S. Subramanian, M.J. Zaworotko, J. Chem. Soc., Chem. Commun. (1994) 1335. T. Otieno, S.J. Rettig, R.C. Thompson, J. Trotter, Inorg. Chem. 32 (1993) 1607.

[5] D.E. Royzman, A.M. Noviello, K.M. Henline, R.D. Pike, J.P. Killarney, H.H. Patterson, C. Crawford, Z. Assefa, J. Inorg. Organomet. Polym. 24 (2014) 66.

[6] F.F.B.J. Janssen, L.P.J. Veraart, J.M.M. Smits, R. de Gelder, A.E. Rowan, Cryst. Growth Des. 11 (2011) 4313.

[7] (a) C. Pena, A.M. Galibert, B. Soula, P.-L. Fabre, G. Bernardinelli, P. Castan, J. Chem. Soc., Dalton Trans. (1998) 239. (b) X.-H. Xie, S.-Z. Zhan, H. Wang, J. Cai, J.-P. He, Transition Met. Chem. 34 (2009) 599. (c) A.I. Aranda Perez, T. Biet, S. Graule, T. Agou, C. Lescop, N.R. Branda, J. Crassous, R. Réau, Chem. Eur. J. 17 (2011) 1337, and references cited therein. (d) R.J. Less, B. Guan, N.M. Muresan, M. McPartlin, E. Reisner, T.C. Wilson, D.S. Wright, Dalton Trans., 41 (2012) 5919. 
[8] (a) G. Pampaloni, R. Peloso, C. Graiff, A. Tiripicchio, Dalton Trans. (2006) 3576. (b) T.H. Le, A. Nafady, N.T. Vo, R.W. Elliott, T.A. Hudson, R. Robson, B.F. Abrahams, L. L. Martin, A.M. Bond, Inorg. Chem. 53 (2014) 3230.

[9] (a) B.F. Hoskins, R. Robson, J. Am. Chem. Soc. 111 (1989) 5962. (b) L. Carlucci, G. Ciani, D.M. Proserpio, A. Sironi, Angew. Chem. 35 (1996) 1088. (c) T. Kuroda-Sowa, T. Horino, M. Yamamoto, Y. Ohno, M. Maekawa, M. Munakata Inorg. Chem. 36 (1997) 6382. (d) T. Kuroda-Sowa, M. Hirata, M. Munakata, M. Maekawa, Chem. Lett. (1998) 499. (e) Y. Suenaga, S.G. Yan, L.P. Wu, I. Ino, T. Kuroda-Sowa, M. Maekawa, M. Munakata J. Chem. Soc., Dalton Trans. (1998) 1121. (f) M. Munakata, G.L. Ning, T. Kuroda-Sowa, M. Maekawa, Y. Suenaga, T. Horino, Inorg. Chem. 37 (1998) 5651. (g) S.R. Batten, B.F. Hoskins, R. Robson, Chem. Eur. J. 6 (2000) 156. (h) S.P. Anthony, T.P. Radhakrishnan, Cryst. Growth Des. 4 (2004) 1223. (i) E.G. Sakellariou, J.-P. Collin, C.O. Dietrich-Bucheker, J.-P. Sauvage, Eur. J. Inorg. Chem. (2004) 575. (j) R.J. Less, T.C. Wilson, M. McPartlin, P.T. Wood, D.S. Wright, Chem. Commun. 47 (2011) 10007. (k) R.J. Less, B. Guan, N.M. Muresan, M. McPartlin, E. Reisner, T.C. Wilson, D.S. Wright, Dalton Trans. 41 (2012) 5919. (1) B.F. Abrahams, R.W. Elliott, T.A. Hudson, R. Robson, Cryst. Growth Des. 13 (2013) 3018.

[10] G.J. Kubas, Inorg. Synth. 28 (1990) 68.

[11] SAINT PLUS: Bruker Analytical X-ray Systems: Madison, WI, 2001.

[12] SADABS: Bruker Analytical X-ray Systems: Madison, WI, 2001.

[13] G.M. Sheldrick, Acta Crystallogr., Sect. A 64 (2008) 112.

[14] C.B. Hübschle, G.M. Sheldrick, B. Dittrich, J. Appl. Cryst. 44 (2011) 1281.

[15] J. Green, E. Sinn, S. Woodward, R. Butcher, Polyhedron 12 (1993) 991.

[16] (a) J.M. Knaust, D.A. Knight, S.W. Keller, J. Chem. Cryst. 33 (2003) 813. (b) G.A. Bowmaker, K.C. Lim, N. Somers, B.W. Skelton, A.H. White, Z. Naturforsch. 59b (2004) 1301. (c) Y. Zhang, W. Sun, C. Freund, A.M. Santos, E. Herdtweck, J. Mink, F.E. Kühn, 
Inorg. Chim. Acta 359 (2006) 4723. (d) V.A.S. Falcomer, S.S. Lemos, G.B.C. Martins, G.A. Casagrande, R.A. Burrow, E.S. Lang, Polyhedron 26 (2007) 3871. (e) J.W. Bats, T. Kretz, H.-W. Lerner, Acta Crystallogr. Sect. C 56 (2009) m94.

[17] (a) A. Dvorsk, J. Kokisek, L. Jager, C. Tretner, Acta Crystallogr. Sect. C 53 (1997) 556.

(b) K.E. Bessler, L.A. de P. Calzavara, V.M. Deflon, E. Niquet, Acta Crystallogr. Sect. C 57 (2001) m522.

[18] (a) S.B. Harkins, J.C. Peters, J. Am. Chem. Soc. 127, 2030 (2005). (b) G. Che, Z. Su, W. Li, B. Chu, M. Li, Z. Hu, Z. Zhang, Appl. Phys. Lett. 89, 103511-1 (2006). (c) A. Tsuboyama, K. Kuge, M. Furugori, S. Okada, M. Hoshino, K. Ueno, Inorg. Chem. 46, 1992 (2007). (d) Q. Zhang, J. Ding, Y. Cheng, L. Wang, Z. Xie, X. Jing, F. Wang, Adv. Funct. Mater. 17, 2983 (2007). (e) A.J.M. Miller, J.L. Dempsey, J.C. Peters, Inorg. Chem. 46, 7244 (2007). (f) Z. Si, J. Li, B. Li, S. Liu, W. Li, J. Lumin. 129, 181 (2009). (g) L. Zhang, B. Li, Z. Su, J. Phys. Chem. C 113, 13968 (2009). (h) J.C. Deaton, S.C. Switalski, D.Y. Kondakov, R.H. Young, T.D. Pawlik, D.J. Giesen, S.B. Harkins, A.J.M. Miller, S.F. Mickenberg, J.C. Peters, J. Am. Chem. Soc. 13: 9499 (2010). 
Table 1. Crystallization results for compound $\mathbf{1}$

\begin{tabular}{lllll}
\hline solvent $^{\mathrm{a}}$ & $\mathrm{CH}_{2} \mathrm{Cl}_{2}$ & $\mathrm{CHCl}_{3}$ & $\mathrm{THF}$ & acetone \\
\hline major product & $\mathbf{1 a}$ & $\mathbf{1 a}$ & $\mathbf{1 e}$ & $\mathbf{1 a}$ \\
minor product(s) & $\mathbf{1 b}, \mathbf{1 c}$ & $\mathbf{1 d}$ & $\mathbf{1 a}$ & none \\
\hline
\end{tabular}

${ }^{\mathrm{a}} 30 \mathrm{mM}$ solution with liquid diffusion of excess ethyl ether 
Table 2. Crystal and Structure Refinement Data.

\begin{tabular}{|c|c|c|c|}
\hline complex & $1 \mathbf{a}$ & $1 \mathbf{b}$ & 1c \\
\hline CCDC deposit no. & 1421639 & 1421640 & 1421641 \\
\hline color and habit & yellow prism & yellow prism & yellow block \\
\hline size, $\mathrm{mm}$ & $0.46 \times 0.28 \times 0.07$ & $0.26 \times 0.21 \times 0.12$ & $0.29 \times 0.23 \times 0.18$ \\
\hline formula & $\mathrm{C}_{88} \mathrm{H}_{68} \mathrm{~B}_{2} \mathrm{Cu}_{2} \mathrm{~F}_{8} \mathrm{~N}_{4} \mathrm{P}_{4}$ & $\mathrm{C}_{88.5} \mathrm{H}_{69} \mathrm{~B}_{2} \mathrm{ClCu}_{2} \mathrm{~F}_{8} \mathrm{~N}_{4} \mathrm{P}_{4}$ & $\mathrm{C}_{89} \mathrm{H}_{70} \mathrm{~B}_{2} \mathrm{Cl}_{2} \mathrm{Cu}_{2} \mathrm{~F}_{8} \mathrm{~N}_{4} \mathrm{P}_{4}$ \\
\hline formula weight & 1606.04 & 1648.50 & 1690.97 \\
\hline space group & $P 2_{1} / \mathrm{c}(\# 14)$ & $P 2{ }_{1} / \mathrm{c}(\# 14)$ & $P-1(\# 2)$ \\
\hline$a, \AA$ & $10.2544(4)$ & $11.6763(2)$ & $12.3208(2)$ \\
\hline$b, \AA$ & $21.8677(9)$ & $41.8821(8)$ & $12.8799(2)$ \\
\hline$c, \AA$ & $17.5324(7)$ & $17.3564(3)$ & $14.1028(2)$ \\
\hline$\alpha, \operatorname{deg}$ & 90 & 90 & $110.3800(10)$ \\
\hline$\beta$, deg & $100.6235(15)$ & $106.9395(8)$ & $96.3860(10)$ \\
\hline$\gamma, \operatorname{deg}$ & 90 & 90 & $104.2460(10)$ \\
\hline volume, $\AA^{3}$ & $3864.1(3)$ & $8119.5(3)$ & 1985.04(5) \\
\hline Z & 2 & 4 & 1 \\
\hline$\rho_{\text {calc }}, \mathrm{g} \mathrm{cm}^{-3}$ & 1.380 & 1.349 & 1.415 \\
\hline $\mathrm{F}_{000}$ & 1648 & 3380 & 866 \\
\hline$\mu(\mathrm{Cu} \mathrm{K} \alpha), \mathrm{mm}^{-1}$ & 2.028 & 2.240 & 2.607 \\
\hline temperature, $\mathrm{K}$ & 100 & 100 & 100 \\
\hline residuals: ${ }^{a} \mathrm{R} ; \mathrm{R}_{\mathrm{w}}$ & $0.0402 ; 0.0992$ & $0.0439 ; 0.1099$ & $0.0371 ; 0.0970$ \\
\hline goodness of fit & 1.079 & 1.101 & 1.045 \\
\hline Flack & - & - & - \\
\hline
\end{tabular}

${ }^{\mathrm{a}} \mathrm{R}=R_{l}=\Sigma|| F_{o}|-| F_{c}|/ \Sigma| F_{o} \mid$ for observed data only. $\mathrm{R}_{\mathrm{w}}=w R_{2}=\left\{\Sigma\left[w\left(F_{o}^{2}-F_{c}^{2}\right)^{2}\right] / \Sigma\left[w\left(F_{o}^{2}\right)^{2}\right]\right\}^{1 / 2}$ for all data. 
Table 2. Cont'd.

\begin{tabular}{|c|c|c|c|}
\hline complex & 1d & 1e & 2 \\
\hline CCDC deposit no. & 1421642 & 1421643 & 1421644 \\
\hline color and habit & colorless block & colorless block & colorless prism \\
\hline size, $\mathrm{mm}$ & $0.29 \times 0.23 \times 0.23$ & $0.41 \times 0.34 \times 0.09$ & $0.50 \times 0.15 \times 0.14$ \\
\hline formula & $\mathrm{C}_{45} \mathrm{H}_{36} \mathrm{BCl}_{2} \mathrm{CuF}_{4} \mathrm{~N}_{2} \mathrm{P}_{2}$ & $\mathrm{C}_{96} \mathrm{H}_{84} \mathrm{~B}_{2} \mathrm{Cu}_{2} \mathrm{~F}_{8} \mathrm{~N}_{4} \mathrm{OP}_{4}$ & $\mathrm{C}_{44} \mathrm{H}_{34} \mathrm{BCuF}_{4} \mathrm{~N}_{2} \mathrm{P}_{2}$ \\
\hline formula weight & 1862.79 & 1750.25 & 803.02 \\
\hline space group & $P-1(\# 2)$ & $P-1(\# 2)$ & $P 2{ }_{1} 2_{1} 2_{1}(\# 19)$ \\
\hline$a, \AA$ & $12.6821(2)$ & $12.2640(2)$ & $14.7185(3)$ \\
\hline$b, \AA$ & $14.6601(2)$ & $12.8363(2)$ & $15.7165(4)$ \\
\hline$c, \AA$ & 23.5991(4) & $14.4960(2)$ & $16.5877(4)$ \\
\hline$\alpha, \operatorname{deg}$ & $96.7010(10)$ & $71.3510(10)$ & 90 \\
\hline$\beta, \operatorname{deg}$ & $96.2570(10)$ & $89.6950(10)$ & 90 \\
\hline$\gamma, \operatorname{deg}$ & $98.3950(10)$ & $78.9790(10)$ & 90 \\
\hline volume, $\AA^{3}$ & $4275.29(12)$ & $2118.51(6)$ & $3837.12(16)$ \\
\hline Z & 2 & 1 & 4 \\
\hline$\rho_{\text {calc }}, \mathrm{g} \mathrm{cm}^{-3}$ & 1.447 & 1.372 & 1.390 \\
\hline $\mathrm{F}_{000}$ & 1900 & 904 & 1648 \\
\hline$\mu(\mathrm{Cu} \mathrm{K} \alpha), \mathrm{mm}^{-1}$ & 3.607 & 1.912 & 2.042 \\
\hline temperature, $\mathrm{K}$ & 100 & 100 & 100 \\
\hline residuals: ${ }^{\mathrm{a}} \mathrm{R} ; \mathrm{R}_{\mathrm{w}}$ & $0.0397 ; 0.1077$ & $0.0367 ; 0.0989$ & $0.0199 ; 0.0515$ \\
\hline goodness of fit & 1.026 & 1.018 & 1.048 \\
\hline Flack & - & - & $-0.005(4)$ \\
\hline
\end{tabular}

${ }^{\mathrm{a}} \mathrm{R}=R_{1}=\Sigma|| F_{o}|-| F_{c}|/ \Sigma| F_{o} \mid$ for observed data only. $\mathrm{R}_{\mathrm{w}}=w R_{2}=\left\{\Sigma\left[w\left(F_{o}^{2}-F_{c}^{2}\right)^{2}\right] / \Sigma\left[w\left(F_{o}^{2}\right)^{2}\right]\right\}^{1 / 2}$ for all data. 
Table 2. Cont'd.

\begin{tabular}{|c|c|c|c|}
\hline complex & $3 \mathbf{a}$ & $3 \mathbf{b}$ & $4 a$ \\
\hline CCDC deposit no. & 1421645 & 1421646 & 1421647 \\
\hline color and habit & yellow prism & yellow block & yellow block \\
\hline size, $\mathrm{mm}$ & $0.29 \times 0.21 \times 0.12$ & $0.50 \times 0.46 \times 0.32$ & $0.36 \times 0.33 \times 0.21$ \\
\hline formula & $\mathrm{C}_{45} \mathrm{H}_{36} \mathrm{BCl}_{2} \mathrm{CuF}_{4} \mathrm{~N}_{2} \mathrm{P}_{2}$ & $\mathrm{C}_{45} \mathrm{H}_{36} \mathrm{BCl}_{2} \mathrm{CuF}_{4} \mathrm{~N}_{2} \mathrm{P}_{2}$ & $\mathrm{C}_{98} \mathrm{H}_{84} \mathrm{~B}_{2} \mathrm{Cu}_{2} \mathrm{~F}_{8} \mathrm{~N}_{4} \mathrm{P}_{4}$ \\
\hline formula weight & 887.95 & 887.95 & 1742.27 \\
\hline space group & $P 2{ }_{1} / \mathrm{c}(\# 14)$ & $P-1(\# 2)$ & $P-1(\# 2)$ \\
\hline$a, \AA$ & $12.3905(3)$ & $12.5424(3)$ & $12.2522(2)$ \\
\hline$b, \AA$ & $49.5897(12)$ & $13.7376(3)$ & $12.9592(2)$ \\
\hline$c, \AA$ & $13.7956(3)$ & $25.7877(6)$ & $15.3617(2)$ \\
\hline$\alpha, \operatorname{deg}$ & 90 & $104.8960(10)$ & $72.5680(10)$ \\
\hline$\beta$, deg & $96.8549(14)$ & $96.9140(10)$ & $84.6590(10)$ \\
\hline$\gamma, \operatorname{deg}$ & 90 & $97.4130(10)$ & $64.7630(10)$ \\
\hline volume, $\AA^{3}$ & $8416.0(3)$ & $4203.06(17)$ & $2103.28(6)$ \\
\hline $\mathrm{Z}$ & 8 & 4 & 1 \\
\hline$\rho_{\text {calc }}, \mathrm{g} \mathrm{cm}^{-3}$ & 1.402 & 1.403 & 1.376 \\
\hline $\mathrm{F}_{000}$ & 3632 & 1816 & 900 \\
\hline$\mu(\mathrm{Cu} \mathrm{K} \alpha), \mathrm{mm}^{-1}$ & 3.057 & 3.060 & 1.906 \\
\hline temperature, $\mathrm{K}$ & 100 & 100 & 100 \\
\hline residuals: ${ }^{\mathrm{a}} \mathrm{R} ; \mathrm{R}_{\mathrm{w}}$ & $0.0600 ; 0.1452$ & $0.0401 ; 0.0969$ & $0.0334 ; 0.0870$ \\
\hline goodness of fit & 1.098 & 1.089 & 1.055 \\
\hline Flack & - & - & - \\
\hline
\end{tabular}

${ }^{\mathrm{a}} \mathrm{R}=R_{l}=\Sigma|| F_{o}|-| F_{c}|| / \Sigma\left|F_{o}\right|$ for observed data only. $\mathrm{R}_{\mathrm{w}}=w R_{2}=\left\{\Sigma\left[w\left(F_{o}{ }^{2}-F_{c}{ }^{2}\right)^{2}\right] / \Sigma\left[w\left(F_{o}{ }^{2}\right)^{2}\right]\right\}^{1 / 2}$ for all data. 
Table 2. Cont'd.

\begin{tabular}{|c|c|c|}
\hline complex & 5 & 6a \\
\hline CCDC deposit no. & 1421648 & 1421649 \\
\hline color and habit & colorless prism & yellow block \\
\hline size, $\mathrm{mm}$ & $0.49 \times 0.31 \times 0.11$ & $0.29 \times 0.26 \times 0.20$ \\
\hline formula & $\mathrm{C}_{126} \mathrm{H}_{102} \mathrm{~B}_{3} \mathrm{Cu}_{3} \mathrm{~F}_{12} \mathrm{~N}_{6} \mathrm{P}_{6}$ & $\mathrm{C}_{43.5} \mathrm{H}_{37} \mathrm{BCl}_{2} \mathrm{CuF}_{4} \mathrm{~N}_{2} \mathrm{O}_{0.5} \mathrm{P}_{2}$ \\
\hline formula weight & 2337.00 & 808.04 \\
\hline space group & $R 3 \mathrm{c}(\# 161)$ & C2/c (\#15) \\
\hline$a, \AA$ & $23.0603(6)$ & $28.2785(6)$ \\
\hline$b, \AA$ & $23.0603(6)$ & $14.6785(3)$ \\
\hline$c, \AA$ & $36.0481(10)$ & $19.8536(4)$ \\
\hline$\alpha, \operatorname{deg}$ & 90 & 90 \\
\hline$\beta, \operatorname{deg}$ & 90 & $110.2040(10)$ \\
\hline$\gamma, \operatorname{deg}$ & 120 & 90 \\
\hline volume, $\AA^{3}$ & $16601.3(10)$ & $7733.9(3)$ \\
\hline Z & 6 & 8 \\
\hline$\rho_{\text {calc }}, \mathrm{g} \mathrm{cm}^{-3}$ & 1.403 & 1.388 \\
\hline $\mathrm{F}_{000}$ & 7200 & 3328 \\
\hline$\mu(\mathrm{Cu} \mathrm{K} \alpha), \mathrm{mm}^{-1}$ & 2.104 & 2.037 \\
\hline temperature, $\mathrm{K}$ & 100 & 100 \\
\hline residuals: ${ }^{a} \mathrm{R} ; \mathrm{R}_{\mathrm{w}}$ & $0.0558 ; 0.1417$ & $0.0915 ; 0.2221$ \\
\hline goodness of fit & 1.052 & 1.305 \\
\hline Flack & $0.80(5)$ & - \\
\hline
\end{tabular}

${ }^{\mathrm{a}} \mathrm{R}=R_{l}=\Sigma|| F_{o}|-| F_{c}|/ \Sigma| F_{o} \mid$ for observed data only. $\mathrm{R}_{\mathrm{w}}=w R_{2}=\left\{\Sigma\left[w\left(F_{o}{ }^{2}-F_{c}{ }^{2}\right)^{2}\right] / \Sigma\left[w\left(F_{o}{ }^{2}\right)^{2}\right]\right\}^{1 / 2}$ for all data. 
Table 3. Selected Bond Distances $(\AA)$ and Angles (deg).

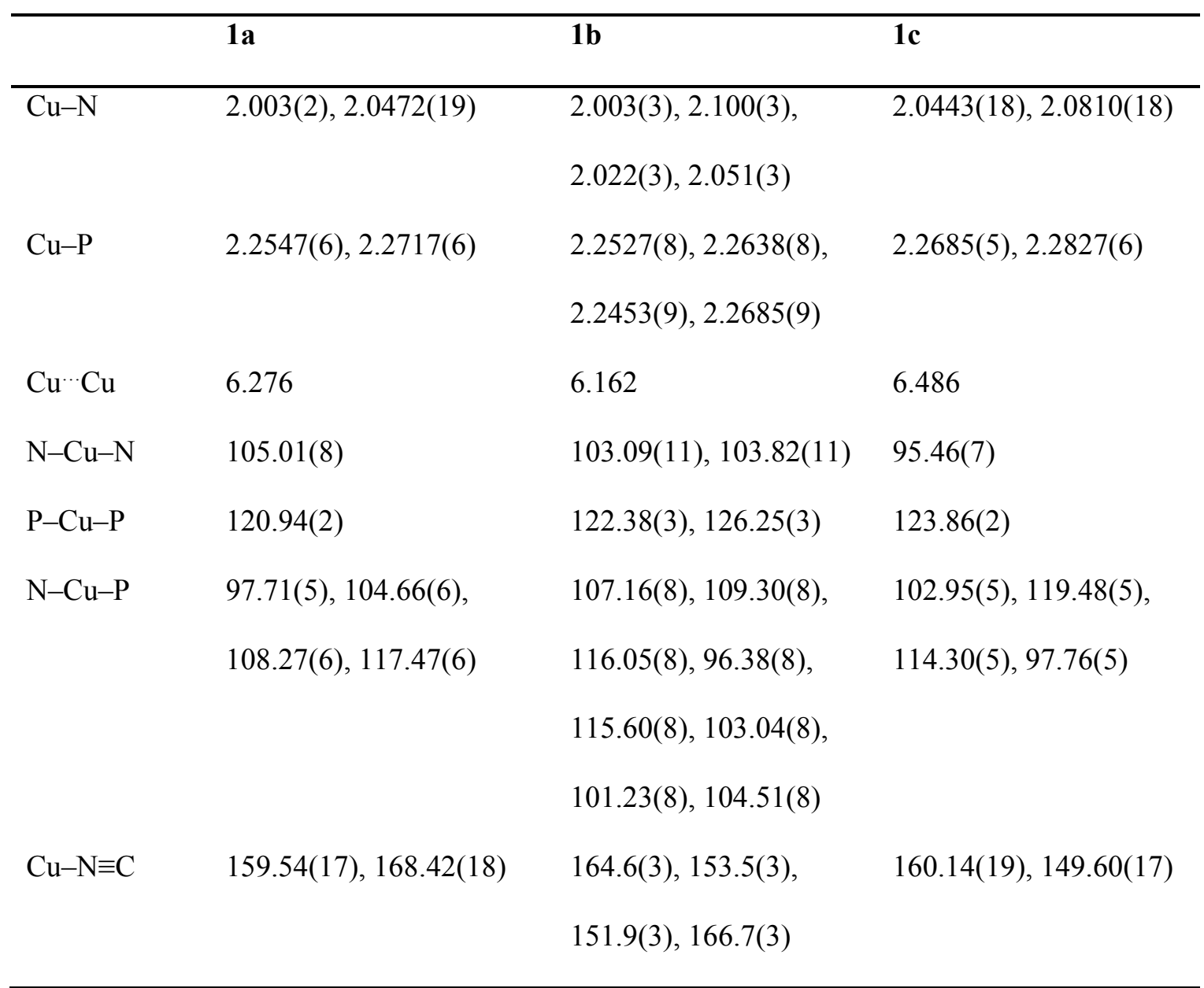

${ }^{\mathrm{a}} \mathrm{N}_{\mathrm{Py}}$ 
Table 3. Contd.

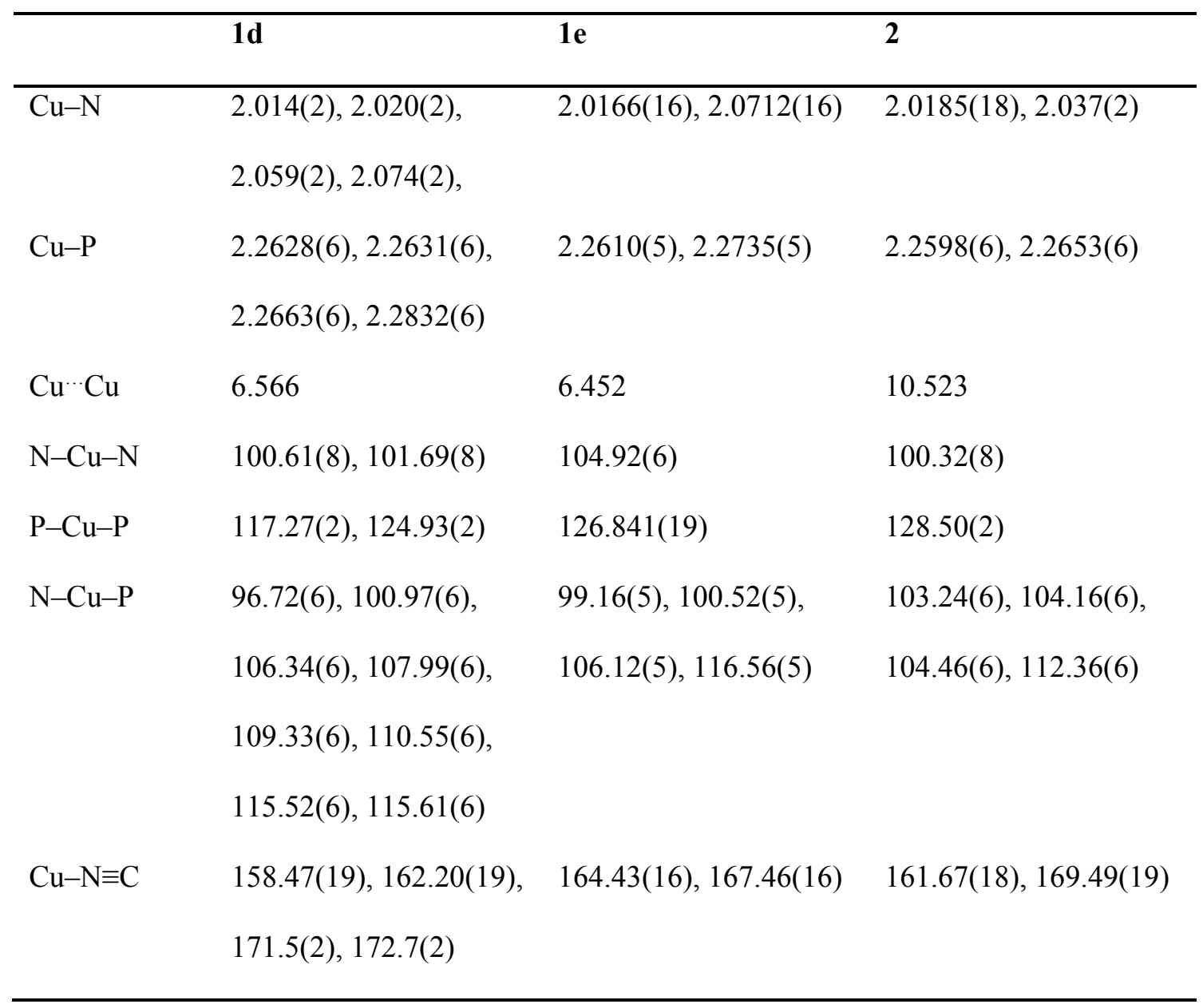

${ }^{\mathrm{a}} \mathrm{N}_{\mathrm{Py}}$ 
Table 3. Contd.

\begin{tabular}{llll}
\hline & 3a & 3b & 4a \\
\hline $\mathrm{Cu}-\mathrm{N}$ & $2.007(3), 2.032(3)$, & $2.0104(18), 2.0277(19)$, & $2.0184(15), 2.1438(15)^{\mathrm{a}}$ \\
& $2.087(3), 2.098(3)$ & $2.0793(19), 2.0810(19)$ & \\
$\mathrm{Cu}-\mathrm{P}$ & $2.2519(10), 2.2639(10)$, & $2.2510(6), 2.2602(6)$, & $2.2724(5), 2.2779(5)$ \\
& $2.2656(10), 2.2880(10)$ & $2.2698(6), 2.2918(6)$ & \\
$\mathrm{Cu} \cdots \mathrm{Cu}$ & $11.398,11.785$ & $11.405,11.801$ & 5.494 \\
$\mathrm{~N}-\mathrm{Cu}-\mathrm{N}$ & $95.89(13), 95.91(13)$ & $95.90(8), 97.29(8)$ & $107.02(6)$ \\
$\mathrm{P}-\mathrm{Cu}-\mathrm{P}$ & $123.92(4), 125.23(4)$ & $124.37(2), 125.45(2)$ & $130.763(19)$ \\
$\mathrm{N}-\mathrm{Cu}-\mathrm{P}$ & $98.74(9), 101.98(10)$, & $99.47(5), 101.66(6)$, & $100.40(4), 103.72(5)$, \\
& $103.31(10), 104.61(10)$, & $102.60(6), 105.30(6)$, & $105.15(5), 108.03(4)$ \\
& $107.09(10), 112.02(10)$, & $105.98(6), 112.04(6)$, & \\
& $113.90(9), 121.43(10)$ & $113.07(6), 120.85(6)$ & \\
& $140.7(3), 148.5(3)$, & $140.32(18), 149.58(19)$, & $170.04(15)$ \\
& $161.9(3), 169.1(3)$ & $162.11(19), 169.22(19)$ & \\
\hline $\mathrm{Cu}-\mathrm{N} \equiv \mathrm{C}$ & & & \\
& & &
\end{tabular}

${ }^{\mathrm{a}} \mathrm{N}_{\mathrm{Py}}$ 
Table 3. Contd.

\begin{tabular}{lll}
\hline & $\mathbf{5}$ & $\mathbf{6 a}$ \\
\hline $\mathrm{Cu}-\mathrm{N}$ & $1.89(2), 1.933(9)$, & $1.98(4), 2.05(2)$, \\
& $2.221(9)^{\mathrm{a}}, 2.39(2)^{\mathrm{a}}$ & $2.14(3)^{\mathrm{a}}, 2.15(2)^{\mathrm{a}}$ \\
$\mathrm{Cu}-\mathrm{P}$ & $2.276(2), 2.281(2)$ & $2.2641(18), 2.2800(18)$ \\
$\mathrm{Cu} \cdots \mathrm{Cu}$ & 8.607 & 9.414 \\
$\mathrm{~N}-\mathrm{Cu}-\mathrm{N}$ & $94.9(8), 96.9(4)$ & $99.4(9), 102.7(13)$ \\
$\mathrm{P}-\mathrm{Cu}-\mathrm{P}$ & $119.05(6)$ & $132.34(7)$ \\
$\mathrm{N}-\mathrm{Cu}-\mathrm{P}$ & $96.3(5), 98.6(2)$, & $96.2(15), 96.9(11)$, \\
& $109.9(5), 112.8(3)$, & $97.5(6), 101.0(7)$, \\
& $113.0(3), 113.3(2)$, & $103.9(7), 110.6(5)$, \\
& $115.2(6), 115.9(7)$ & $116.0(11), 117.0(15)$ \\
& $168.5(11)$ & $165(4), 173.5(16)$ \\
\hline $\mathrm{Cu}-\mathrm{N} \equiv \mathrm{C}$ & &
\end{tabular}

${ }^{a} \mathrm{~N}_{\mathrm{Py}}$ 
Table 4: Solid state luminescence data for complexes 1-6.

\begin{tabular}{|c|c|c|c|c|}
\hline Complex & Temp., K & $\lambda_{\max }$, Excitation $(\mathrm{nm})$ & $\lambda_{\max }$, Emission $(\mathrm{nm})$ & Stokes Shift $\left(\mathrm{cm}^{-1}\right)$ \\
\hline \multirow[t]{2}{*}{1} & 298 & 398 & 518 & 5,820 \\
\hline & 77 & 398 & 518 & 5,820 \\
\hline \multirow[t]{2}{*}{2} & 298 & 351 & 485 & 7,870 \\
\hline & 77 & 346 & 488 & 8,410 \\
\hline \multirow[t]{2}{*}{3} & 298 & 400 & 509 & 5,350 \\
\hline & 77 & 380 & 512 & 6,780 \\
\hline \multirow[t]{2}{*}{4} & 298 & 352 & 518 & 9,100 \\
\hline & 77 & 354 & 564 & 10,500 \\
\hline \multirow[t]{2}{*}{5} & 298 & 341 & 493 & 9,040 \\
\hline & 77 & 355 & 509 & 8,520 \\
\hline \multirow[t]{2}{*}{6} & 298 & 380 & 546 & 8,000 \\
\hline & 77 & 356 & 559 & 10,200 \\
\hline
\end{tabular}


$3\left[\mathrm{Cu}(\mathrm{NCMe})_{4}\right] \mathrm{BF}_{4}$
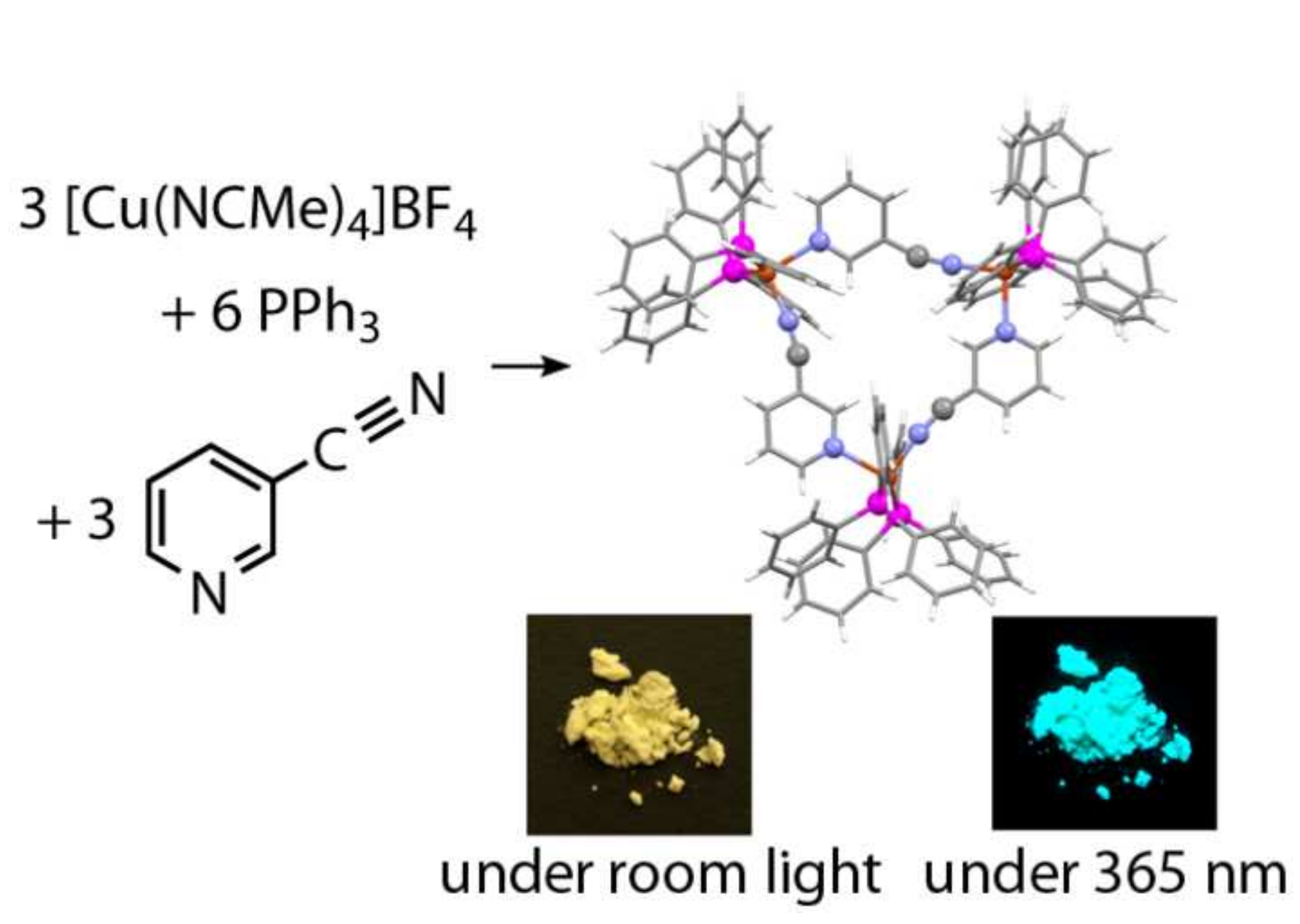

under room light under $365 \mathrm{~nm}$ $+6 \mathrm{PPh}_{3}$

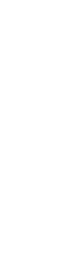

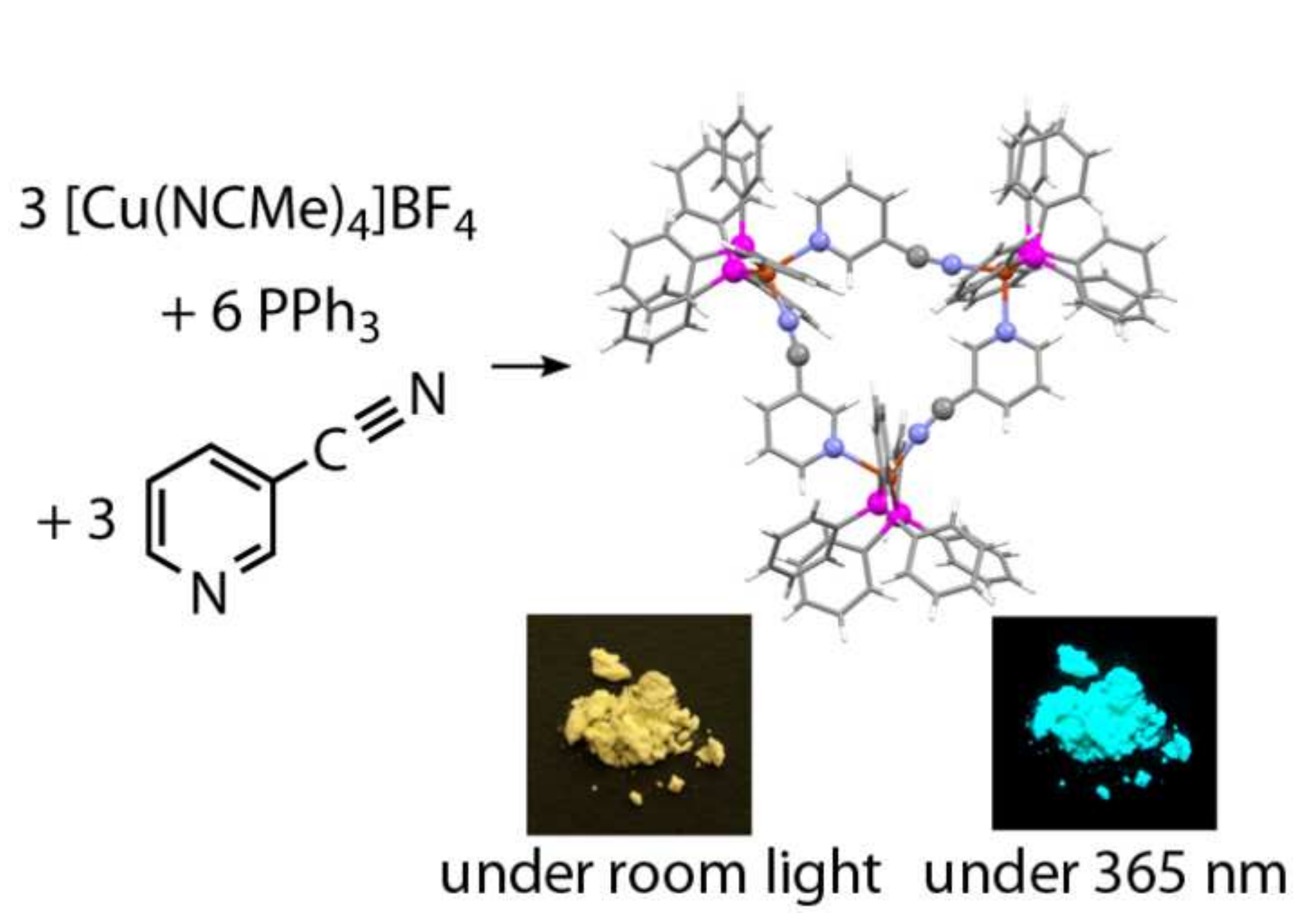
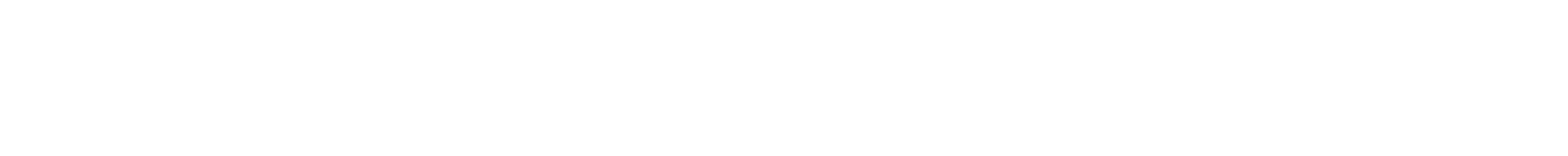

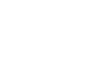

